\title{
Factors Influencing Carbon Stocks and Accumulation Rates in Eelgrass Meadows Across New England, USA
}

\author{
A. B. Novak ${ }^{1}$ (1) M. C. Pelletier ${ }^{2}$ P. Colarusso ${ }^{3} \cdot$ J. Simpson $^{4} \cdot$ M. N. Gutierrez ${ }^{2} \cdot$ A. Arias-Ortiz $^{5,6} \cdot$ M. Charpentier ${ }^{7}$. \\ P. Masque ${ }^{5,8,9,10}$. P. Vella ${ }^{11}$
}

Received: 7 May 2019 / Revised: 13 April 2020 / Accepted: 30 April 2020 / Published online: 27 May 2020

(C) The Author(s) 2020

\begin{abstract}
Increasing the protection of coastal vegetated ecosystems has been suggested as one strategy to compensate for increasing carbon dioxide $\left(\mathrm{CO}_{2}\right)$ in the atmosphere as the capacity of these habitats to sequester and store carbon exceeds that of terrestrial habitats. Seagrasses are a group of foundation species that grow in shallow coastal and estuarine systems and have an exceptional ability to sequester and store large quantities of carbon in biomass and, particularly, in sediments. However, carbon stocks $\left(\mathrm{C}_{\text {org }}\right.$ stocks) and carbon accumulation rates $\left(\mathrm{C}_{\text {org }}\right.$ accumulation) in seagrass meadows are highly variable both spatially and temporally, making it difficult to extrapolate this strategy to areas where information is lacking. In this study, $\mathrm{C}_{\text {org }}$ stocks and $\mathrm{C}_{\text {org }}$ accumulation were determined at 11 eelgrass meadows across New England, representing a range of eutrophication and exposure conditions. In addition, the environmental factors and structural characteristics of meadows related to variation in $\mathrm{C}_{\text {org }}$ stocks were identified. The objectives were accomplished by assessing stable isotopes of $\delta^{13} \mathrm{C}$ and $\delta^{15} \mathrm{~N}$ as well as $\% \mathrm{C}$ and $\% \mathrm{~N}$ in plant tissues and sediments, measuring grain size and ${ }^{210} \mathrm{~Pb}$ of sediment cores, and through assessing site exposure. Variability in $\mathrm{C}_{\text {org }}$ stocks in seagrass meadows is well predicted using commonly measured environmental variables such as grain size distribution. This study allows incorporation of data and insights for the northwest Atlantic, where few studies on carbon sequestration by seagrasses have been conducted.
\end{abstract}

Keywords Seagrass $\cdot$ Blue carbon $\cdot$ Carbon sequestration $\cdot$ New England

\section{Introduction}

The concentration of carbon dioxide $\left(\mathrm{CO}_{2}\right)$ in the atmosphere has increased from 280 to $410 \mathrm{ppm}$ since pre-industrial times

Communicated by Just Cebrian

Electronic supplementary material The online version of this article (https://doi.org/10.1007/s12237-020-00754-9) contains supplementary material, which is available to authorized users.

\section{A. B. Novak}

abnovak@bu.edu

1 Earth and Environment, Boston University, Boston, MA, USA

2 Atlantic Ecology Division, US EPA, ORD, NHEERL, Narragansett, RI, USA

3 US EPA, Region 1, Boston, MA, USA

4 MIT Sea Grant, Cambridge, MA, USA

5 Institut de Ciència i Tecnologia Ambientals, Universitat Autònoma de Barcelona, Bellaterra, 08193 Barcelona, Spain and is expected to increase to $990 \mathrm{ppm}$ by the end of this century. The accelerated increase of $\mathrm{CO}_{2}$ is primarily due to anthropogenic activities such as the burning of fossil fuels and the modification of land use for agriculture and deforestation
6 Ecosystem Science Division, Department of Environmental Science, Policy and Management, University of California, Berkeley, CA, USA

7 General Dynamics Corporation, Narragansett, RI, USA

8 School of Science and Centre for Marine Ecosystems Research, Edith Cowan University, Joondalup, Western Australia 6027, Australia

9 Departament de Física, Universitat Autònoma de Barcelona, Bellaterra, 08193 Barcelona, Spain

10 International Atomic Energy, 4a Quai Antoine 1er, 98000 Principality of Monaco, Monaco

11 Massachusetts Coastal Zone Management, Boston, MA, USA 
(IPCC 2018). One strategy that has been proposed to mitigate for rising $\mathrm{CO}_{2}$ is to increase protection and restoration of coastal vegetated ecosystems (e.g., saltmarshes, mangroves, seagrasses; Mcleod et al. 2011; Howard et al. 2014). While coastal vegetated ecosystems comprise only $0.05 \%$ of the plant biomass on land, they store a comparable amount of carbon per year, making them one of the most important carbon sinks and mitigators of excess of $\mathrm{CO}_{2}$ on the planet (Smith 1981; Duarte et al. 2005; Nellemann et al. 2009; Mcleod et al. 2011).

Seagrasses are a group of foundation species that grow in shallow coastal and estuarine systems. They form extensive meadows, ranging from a few square meters to hundreds of square kilometers, and can be found along every continent except Antarctica (Green and Short 2003). Seagrass meadows provide many ecosystem services such as improved water quality and clarity, increased biodiversity and habitat, sediment stabilization, and nutrient accumulation (Orth et al. 2006). Like other vegetated coastal ecosystems, seagrasses also sequester and store large quantities of carbon in biomass and in sediments (Smith 1981; Duarte et al. 2005; Fourqurean et al. 2012; Röhr et al. 2018). Seagrass aboveground biomass is considered a short-term carbon sink and has a low contribution to the total carbon $\left(\mathrm{C}_{\text {org }}\right)$ deposits found in meadows (Mateo et al. 2006; Fourqurean et al. 2012) due to exposure to aerobic conditions and herbivory (Enriquez et al. 1993; Mateo et al. 2006; Fourqurean et al. 2012). In contrast, sediments in seagrass meadows are considered a long-term carbon sink with large amounts of $\mathrm{C}_{\text {org }}$ deposits formed by refractory belowground biomass, seagrass detritus, as well as allochthonous $\mathrm{C}_{\text {org }}$ materials (e.g., marsh grass, macroalgae, benthic diatoms, phytoplankton, and seston; Gacia and Duarte 2001; Bouillon and Boschker 2006; Kennedy et al. 2010). Once the carbon accumulates in the sediment, it can remain there for decades to centuries due to anoxic conditions that inhibit microbial activity (Howard et al. 2014; Chmura et al. 2003; Trevathan-Tackett et al. 2017a). Recent assessments suggest that $300,000-600,000 \mathrm{~km}^{2}$ of the ocean is covered in seagrass habitats $(0.1 \%$ of ocean surface), potentially storing between 4.2 and $8.4 \mathrm{Pg} \mathrm{C}$, contributing to $10 \%$ of the annual carbon burial in the ocean (Duarte et al. 2005; Fourqurean et al. 2012).

Carbon storage $\left(\mathrm{C}_{\text {org }}\right.$ stocks $)$ and carbon accumulation rates ( $\mathrm{C}_{\text {org }}$ accumulation) in seagrass meadows have been shown to vary spatially and temporally (Lavery et al. 2013; SamperVillarreal et al. 2016; Gullström et al. 2018) and are influenced by a number of factors (see review by Mazarrasa et al. 2018). Biotic factors such as species composition, plant morphology (Lavery et al. 2013; Gillis et al. 2017), meadow structural complexity (Jankowska et al. 2016), and carbon origin (Mazarrasa et al. 2017) have been shown to influence $C_{\text {org }}$ stocks in seagrass meadows. Abiotic factors such as water depth, wave height and exposure, and turbidity have also been shown to influence $\mathrm{C}_{\text {org }}$ stocks, with higher content at shallower depths, lower wave heights and exposures, and higher turbidities (Serrano et al. 2014; Samper-Villarreal et al. 2016; Mazarrasa et al. 2017). Elevated carbon in seagrass sediments has been associated with higher proportions of fine sediments, as well as with higher porosity, salinity, lower bulk density, and higher specific surface area (Röhr et al. 2016, 2018; Dahl et al. 2016; Gullström et al. 2018; Miyajima et al. 2017). While the effect of nutrient availability on $\mathrm{C}_{\text {org }}$ accumulation in sediments has been assessed through field and laboratory experiments, the relationship remains unclear (Armitage and Fourqurean 2016; Howard et al. 2016). In addition, the role of biotic and abiotic factors at different scales is poorly understood and critical to explaining interhabitat variability and estimating carbon budgets.

Eelgrass (Zostera marina L.) is the dominant seagrass species of north temperate oceans and a critical natural resource in coastal ecosystems. Along the east coast of the USA, it is estimated that up to $50 \%$ of all eelgrass habitat has been lost in the past century and the prospects for recovery in most of this area are low (Green and Short 2003; Neckles et al. 2009). The greatest anthropogenic threats have been eutrophication and sedimentation from urban and agricultural runoff (Short and Wyllie-Echiverra, 1996; Short et al. 2006; Waycott et al. 2009). Both eutrophication and sedimentation decrease the amount of light available to eelgrass for photosynthesis. Moreover, in systems with high nutrient loadings, epiphytes and fast-growing macroalgae outcompete eelgrass since they uptake nutrients more effectively and have relatively lower light requirements to sustain growth (Harlin and ThorneMiller 1981; Short and Kaldy 1995; Twilley et al. 1985). Other anthropogenic activities having direct impacts on the distribution of eelgrass by reducing water clarity and/or uprooting plants include dredge and fill, land reclamation, and dock and jetty construction. The direct loss of eelgrass by organisms other than humans has also occurred through overgrazing (e.g., geese), bioturbation, and disease (Short and Wyllie-Echeverria 1996). Regardless of the cause, the loss of eelgrass results in the loss of ecosystem services they provide, including $\mathrm{C}_{\text {org }}$ sequestration, and potentially leads to $\mathrm{CO}_{2}$ emissions when sediment $\mathrm{C}_{\text {org }}$ deposits are eroded and exposed to aerobic conditions (Marba et al. 2015; Serrano et al. 2016a; Lovelock et al. 2017).

Despite the attention seagrasses have received as an important habitat for carbon storage, site-specific research is needed to understand how factors such as nutrient availability influence $\mathrm{C}_{\text {org }}$ stocks and $\mathrm{C}_{\text {org }}$ accumulation at various spatial scales. In this study, we contrasted $\mathrm{C}_{\text {org }}$ stocks, $\mathrm{C}_{\text {org }}$ accumulation rates, and sources of accumulated carbon in eelgrass meadows at 11 locations in New England representing a range of eutrophication and exposure conditions. Specifically, the objectives of our study were to quantify $\mathrm{C}_{\text {org }}$ stocks and $\mathrm{C}_{\text {org }}$ accumulation at local scales and for the region, as well as 
identify the environmental factors and structural characteristics of meadows related to variation in $\mathrm{C}_{\text {org }}$ stocks.

\section{Materials and Methods}

\section{Study Area}

Eleven locations with persistent eelgrass meadows were selected from Maine to Rhode Island (Fig. 1, Table 1). A nutrient gradient was confirmed across sites using the methodology of Lee (2004; Fig. S1) with nitrogen in eelgrass leaves ranging from 0.93 to $2.44 \%$. Sites also represented a range of physical exposure: Great Bay, Orleans, West Falmouth, and Charlestown are fully enclosed embayments: Nahant and Cohasset are exposed coastal sites, and the remaining sites have some partial enclosure. With the exception of Great Bay, all sites have generally high salinity (29-32), although there may be intermittent freshwater inputs. Sediment texture ranges from silt to medium sand. Tides range from $0.55 \mathrm{~m}$ at sites from Cohasset and north to $1.13 \mathrm{~m}$ from Orleans and south (Table 1). All sites except Portland Harbor, Boston Harbor, and Prudence Island were sampled during the summer of 2016. The remaining three sites were sampled during the summer of 2017. Samples were collected from the middle of each meadow, at least $6 \mathrm{~m}$ from the meadow's edge in all directions. Water column depths ranged from 1 to $2 \mathrm{~m}$, with the exception of Gloucester, which was approximately $5 \mathrm{~m}$. Samples were also collected outside of each meadow in an unvegetated location.

\section{Field Collection}

Sediment Traps Sediment traps were deployed at each site to provide insights into the amount and type of material being delivered to the meadow and unvegetated site. Six sediment

Fig. 1 Map of study area

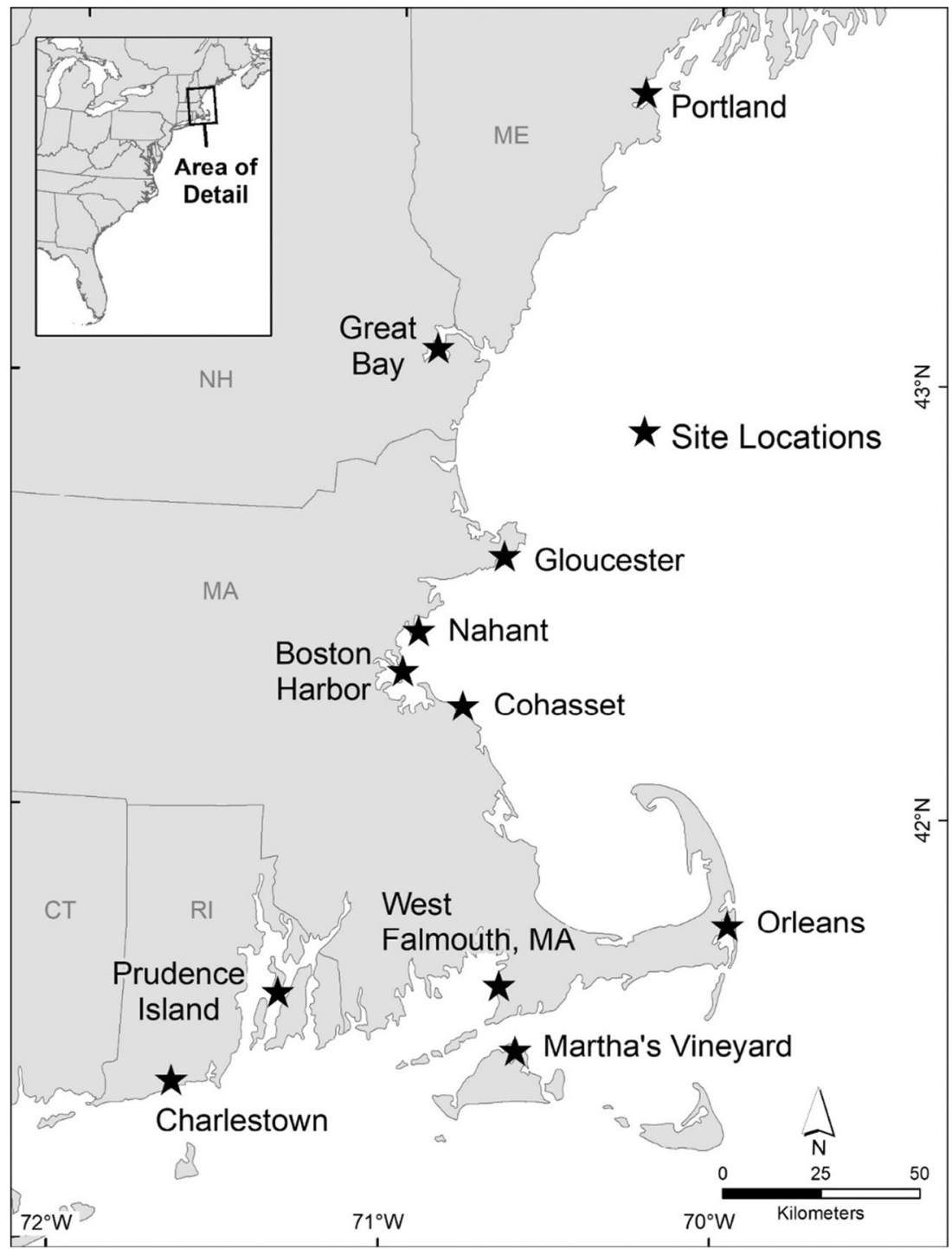


Table 1 Site characteristics. Sites are arranged from north to south. Relative exposure is based on the amount of enclosure at the site and fetch at eelgrass sites. Tidal ranges were obtained from NOAA datums (https://tidesandcurrents.noaa.gov/stations.html?type=Datums). The average salinity and range (in brackets) were obtained from the US
EPA's National Coastal Assessment Program (http://www.epa.gov/ emap). Substrate is the median grain size from the top $5 \mathrm{~cm}$ of the meadow sediment cores from this study, summarized as the appropriate Wentworth class

\begin{tabular}{|c|c|c|c|c|c|c|c|}
\hline Site & Latitude (dd) & Longitude (dd) & Relative exposure & Tidal range (m) & $\begin{array}{l}\% \text { Nitrogen } \\
\text { in eelgrass }\end{array}$ & Salinity (psu) & Substrate \\
\hline Portland, ME & 43.67 & -70.24 & Moderate & $2.78-3.02$ & 2.44 & $30.8(29.0-31.7)$ & Very fine sand \\
\hline Great Bay, NH & 43.07 & -70.88 & Moderate & $2.05-2.25$ & 1.74 & $25.9(16.5-30.9)$ & Silt \\
\hline Gloucester, MA & 42.60 & -70.66 & Low & $2.68-2.92$ & 1.13 & $31.6(30.1-33.6)$ & Medium sand \\
\hline Nahant, MA & 42.42 & -70.92 & Moderate & $2.89-3.13$ & 1.08 & $31(30.2-31.4)$ & Fine sand \\
\hline Boston Harbor, MA & 42.33 & -70.96 & Moderate & $2.89-3.13$ & 1.56 & $30.3(24.6-32.9)$ & Very fine sand \\
\hline Cohasset, MA & 42.25 & -70.78 & High & $2.89-3.13$ & 1.18 & $30.3(29.8-30.8)$ & Fine sand \\
\hline Orleans, MA & 41.75 & -69.95 & Low & $1.20-1.40$ & 1.32 & $30.7(30.2-31.5)$ & Very fine sand \\
\hline W. Falmouth, MA & 41.61 & -70.65 & Low & $0.55-0.67$ & 0.93 & $30.1(29.5-31.0$ & Medium sand \\
\hline Prudence Island, RI & 41.58 & -71.32 & High & $1.14-1.26$ & 1.71 & $30.4(19.5-32.9)$ & Medium sand \\
\hline Martha's Vineyard, MA & 41.46 & -70.60 & Moderate & $0.85-0.95$ & 0.97 & $28.7(18.1-31.8)$ & Fine sand \\
\hline Charlestown, RI & 41.37 & -71.64 & Low & $0.77-0.88$ & 1.16 & $29.6(26.0-32.3)$ & Silt \\
\hline
\end{tabular}

trap arrays, with three traps per array, were deployed for 14 days at the sediment surface at each site to quantify sediment deposition. At each of the 11 sites, three arrays (Fig. S2) were placed inside the meadow and three arrays were placed outside the meadow on bare substrate. Each trap consisted of a PVC tube (length $15 \mathrm{~cm}$, inner diameter $5 \mathrm{~cm}$ ). A honeycomb baffle (Plascore, Zeeland, MI) was placed inside each trap to prevent resuspension of particles.

Sediment Cores Nine sediment cores (five within the meadow and four from adjacent unvegetated sites outside of the meadow) were taken at each site. A 50-cm core barrel (diameter $7 \mathrm{~cm}$ ) was manually driven to the point of refusal using a core head with a T handle and check valve. Cores were extracted, capped at both ends under water, and kept in a vertical position during transport to shore. Compaction during sampling was observed in 7 of the sites and was assessed by measuring the depth to the sediment surface inside and outside of the core. The depth of refusal averaged $30 \mathrm{~cm}$ (decompressed) except for Charlestown and Great Bay where it was not reached. Carbon stock estimates were then normalized to $30 \mathrm{~cm}$ which is close to the depth of refusal in most of the sites, thus include the full range of seagrass organic carbon deposits. Eight of the cores (four meadow and four unvegetated) were divided into sections $(0-2 \mathrm{~cm}, 2-5 \mathrm{~cm}$, 5-10 cm, 10-20 cm, 20-30 cm). Six of the cores were used to measure dry bulk density, sediment organic matter (OM) content (as loss on ignition), $\% \mathrm{C}, \% \mathrm{~N}$, and stable isotopes of $\delta^{13} \mathrm{C}$ and $\delta^{15} \mathrm{~N}$ while two of the cores (one within and one outside of the meadow) were used to measure grain size. The final core from within the meadow was extruded into $1-\mathrm{cm}$ sections from which a 10-15-g subsample was taken from each section for ${ }^{210} \mathrm{~Pb}$ analysis and age determination. In these cores, dry bulk density and \% $\mathrm{C}$ and $\% \mathrm{~N}$ were determined at 2 cm intervals.

Eelgrass Shoot density of each meadow was determined by randomly tossing a $0.0625-\mathrm{m}^{2}$ quadrat $(n=5)$ within a $4-\mathrm{m}$ radius of the sediment traps at each site. Shoot density was estimated in situ by counting the number of shoots within each quadrat.

For morphological measurements, 21 to 30 representative shoots, consisting of both aboveground and belowground material, were collected within a 3-m radius of the sediment traps at each site. An additional 10 eelgrass shoots were haphazardly collected from the middle of the meadow at each site for analyses of $\delta^{13} \mathrm{C}, \delta^{15} \mathrm{~N}, \% \mathrm{C}$, and $\% \mathrm{~N}$ content.

Growth of individual leaves was determined using the leaf marking techniques described by Short (1987). Thirty shoots located within the vicinity of sediment traps were haphazardly selected at each site except Boston Harbor and marked by making a pinhole with a safety pin through the leaf sheath. Fourteen days after initial marking, the shoots were harvested and the distance between the pinhole on each leaf and the residual scar on the sheath was measured along with leaf width, leaf length, and the dried leaf weight of the youngest fully mature leaf. If a young leaf did not have a pinhole, it was considered new growth. The total area of new tissue added per shoot was divided by the number of days, and a linear relationship was developed between leaf weight and length (Short and Duarte 2001). Shoot growth rate is expressed as mg dry weight/shoot/day and $\mathrm{cm} /$ shoots/day. Marked shoots from Martha's Vineyard could not be found and were, therefore, not assessed. 


\section{Laboratory Analysis}

Sediment Traps After field deployment, the sediment traps were capped, returned to the laboratory, and allowed to settle for $4 \mathrm{~h}$ at room temperature. The baffles were then removed, the overlaying water was drained, and the three traps in each array were combined and decanted into one beaker. Fresh vegetation, shells, or small living organisms (fish, shrimp, etc.) were removed from the sample. The sediment was then transferred to a pre-weighed pan and dried to a constant weight for $48 \mathrm{~h}$ at $60{ }^{\circ} \mathrm{C}$. After the sediment was dried to a constant weight, the weight was determined. The material was then crushed into a fine powder and analyzed for $\delta^{13} \mathrm{C}$ and ${ }^{\delta 15} \mathrm{~N}$ as well as carbon $(\% \mathrm{C})$ and nitrogen $(\% \mathrm{~N})$ content (see "Stable Isotope Analysis" section below). Sediment traps for Boston Harbor were lost and were, therefore, not analyzed.

Sediment Cores Dry bulk density of each sediment core section was determined using the mass of sediments dried at $60{ }^{\circ} \mathrm{C}$ for 7 days until they reach a constant weight and then divided by the volume of the sediment section. Following bulk density measurements, the sample was subdivided using a sediment splitter to obtain a smaller portion for stable isotope and organic matter analyses. Shells as well as large rhizomes and roots were removed from the subsample as the goal of this study was to quantify only carbon accumulation from deposition and fragmentation of autochthonous and allochthonous materials (Greiner et al. 2013). The remaining material was homogenized by grinding to a fine powder.

For samples collected in 2016, each processed sample was divided into two subsamples. The first was analyzed for $\delta^{13} \mathrm{C}$, $\delta^{15} \mathrm{~N}, \% \mathrm{C}$, and $\% \mathrm{~N}$, while the second was placed in a muffle furnace at $450{ }^{\circ} \mathrm{C}$ for $16 \mathrm{~h}$ to determine $\% \mathrm{OM}$ using the loss on ignition method (Howard et al. 2014). Studies of $\mathrm{C}_{\text {org }}$ stocks have used both \% $\mathrm{C}$ and organic matter determined using loss on ignition, so to facilitate comparison across studies, both techniques were applied in 2016. In 2017, only $\delta^{13} \mathrm{C}$, $\delta^{15} \mathrm{~N}, \% \mathrm{C}$, and $\% \mathrm{~N}$ were measured.

Grain size was determined for each sediment core section using the Malvern Mastersizer 2000 with the Hydro 2000S wet dispersion unit (Malvern Instruments, Malvern, UK) system. Sediment samples were homogenized and extruded through a 2-mm sieve into a beaker; then, deionized water was added to the sample to create a suspension that was then analyzed.

Eelgrass The morphological samples were rinsed with deionized water and thoroughly cleaned of epiphytes prior to counting the number of leaves per shoot and measuring leaf length $(\mathrm{cm})$, leaf width $(\mathrm{cm})$, and the distance between nodes on the rhizome (internode length; $\mathrm{cm}$ ). Aboveground and belowground material on each shoot was then separated, dried for $48 \mathrm{~h}$ at $60{ }^{\circ} \mathrm{C}$ until it reached a constant weight, and weighed to determine the aboveground and belowground weight $(\mathrm{g})$ of each shoot. The first fully mature leaf from each shoot collected for chemical analysis was cleaned, dried, and ground to a fine powder before analysis.

Stable Isotope Analysis Stable isotope analyses of $\delta^{13} \mathrm{C}$ and $\delta^{15} \mathrm{~N}$, as well as measurements of $\% \mathrm{C}$ and $\% \mathrm{~N}$, were measured in plant and sediment samples using the Isoprime 100 isotope ratio mass spectrometer (IRMS) interfaced with a Micro Vario Elemental Analyzer (Elementar Americas, Mt. Laurel, NJ). Sediment trap, core, and eelgrass samples were weighed into $6 \times 4 \mathrm{~mm}$ tin capsules $(10-15 \mathrm{mg}, 25-30 \mathrm{mg}$, and 4-6 mg, respectively). Due to low amounts of nitrogen in the core sediments, samples were double-tinned when necessary (tin acting as a catalyst for a greater combustion in the IRMS). Internal laboratory standards were used throughout runs, every 15-20 samples, to account for instrument offset (BCSS-1 for sediments and blue mussel homogenate for eelgrass). The $\% \mathrm{C}$ in seagrass leaves was based on 3 composite samples.

Core Dating Analysis ${ }^{210} \mathrm{~Pb}$ was determined through the analysis of ${ }^{210}$ Po by alpha spectrometry after addition of ${ }^{209} \mathrm{Po}$ as an internal tracer and digestion in acid media using an analytical microwave (Sanchez-Cabeza et al. 1998). The concentrations of excess ${ }^{210} \mathrm{~Pb}$ used to obtain the age models were determined as the difference between total ${ }^{210} \mathrm{~Pb}$ and ${ }^{226} \mathrm{Ra}$ (supported ${ }^{210} \mathrm{~Pb}$ ). Concentrations of ${ }^{226} \mathrm{Ra}$ were determined for selected samples along each core using two methods: the ultra-low-level liquid scintillation spectrometer Wallac 1220 Quantulus (PerkinElmer, Waltham, MA) using a technique adapted from Masqué et al. (2002) and gamma spectrometry through the emission lines at 295 and $352 \mathrm{keV}$ of its decay product ${ }^{214} \mathrm{~Pb}$ using calibrated geometries in a HPGe detector (CANBERRA, Mod. SAGe Well). The CF/CS model was used to calculate mean sedimentation rates over the last 100 years at all sites (Krishnaswami et al. 1971; Arias-Ortiz et al. 2018a). The CRS model (Appleby and Oldfield 1978) was also used to calculate sedimentation rates at Niles Beach. This model could not be applied to the other cores because excess ${ }^{210} \mathrm{~Pb}$ was not analyzed for all sections and/or the horizon of excess ${ }^{210} \mathrm{~Pb}$ was not reached (i.e., the sediment cores were too short). $\mathrm{C}_{\text {org }}$ accumulation was calculated by multiplying the average mass accumulation rate by the weighted average of C (\% dry weight) content of the dated period.

\section{Calculations}

Carbon Stock $\mathrm{C}_{\text {org }}$ stocks in the sediment traps were calculated by multiplying the $\% \mathrm{C}$ by the amount of material in the sediment traps and dividing by the sediment trap surface area. The depth-integrated $\mathrm{C}_{\text {org }}$ stocks were calculated according to Lavery et al. (2013) by multiplying the \% C measured along 
the sediment core by the corresponding dry sediment bulk density $\left(\mathrm{g} / \mathrm{cm}^{3}\right)$. These numbers were then depth-integrated over the core length to estimate $\mathrm{C}_{\text {org }}$ stocks. $\mathrm{C}_{\text {org }}$ stocks were normalized to a depth of $30 \mathrm{~cm}$ similar to the average depth of refusal. The eelgrass carbon stock was determined by multiplying \%C by the aboveground eelgrass weight ( $\mathrm{g} / \mathrm{shoot}$ ) by shoot density.

Physical Exposure Physical exposure was determined by calculating relative wave energy (RWE) using WEMo (wave exposure model; https:/coastalscience.noaa.gov/research/ coastal-change/wemo/), and by calculating degree of sorting (Folk and Ward 1957), a proxy for exposure (Röhr et al. 2018) based on the grain size distribution. WEMo uses linear wave theory to calculate actual wave height and derived wave energy while taking into consideration wind generation and local water depth characteristics such as shoaling and dissipation from breaking waves. WEMo modeling was performed using present default value conditions as specified in Fonseca and Malhotra (2010).

\section{Statistical Analysis}

Determination of Differences Among Sites Morphological and structural variation across eelgrass populations was analyzed using a multivariate analysis of variance (MANOVA). The MANOVA indicated significant differences among populations as well as multicollinearity. Three dependent variables (leaf length, leaf width, and aboveground weight) had a partial correlation above 0.7 with leaf area, and one dependent variable (belowground weight) had a partial correlation with internode length. The four dependent variables were removed before conducting individual analyses of variance (ANOVAs) on the remaining dependent variables (number of leaves, internode length, leaf area, aboveground to belowground weight) followed by Tukey's post hoc tests using JMP. Oneway ANOVA was also conducted on shoot density and growth measurements.

Two-way ANOVA was used to analyze differences between sites in carbon stocks $\left(\mathrm{g} \mathrm{C}^{2} \mathrm{~m}^{2}\right)$ in sediment traps and sediment cores using SAS (version 9.4, SAS Institute Inc.). Carbon stocks in the aboveground eelgrass could not be compared statistically because shoot density, morphology, and carbon content were not collected from the same sample. Among site comparisons for plant morphology, meadow structure, and growth were made using one way-ANOVA and Tukey's post hoc tests using JMP (version 12.1, SAS Institute Inc.). All datasets met the assumptions of equal variance according to the Browne-Forsythe test. Values are reported as means and standard errors.

Relating Environmental Variables to Carbon Stocks Multimodel inference (Burnham and Anderson 2002) was used to investigate the relationship between carbon stocks and various environmental variables. In this approach, multiple models are created using all possible combinations of the independent variables thought to be important to the variable being modeled. Linear regression models were generated using SAS 9.4. The carbon stocks in the top $5 \mathrm{~cm}$ of the core (the root zone) were predicted, with separate models for the meadow cores and unvegetated cores.

Because carbon stocks appeared to be related to latitude, variables related to latitude that were also thought to impact seagrass meadows were assembled. Tidal range was obtained from NOAA datums (https://tidesandcurrents.noaa.gov/ stations.html?type $=$ Datums). Water temperature was obtained from EPA's National Coastal Assessment Program (http://www.epa.gov/emap). Insolation was obtained from NASA (https://power.larc.nasa.gov/data-access-viewer/). All three variables were significantly correlated with latitude but because water temperature was significantly related to tidal range $(r=-0.596, p=0.003$, Table $\mathrm{S} 1)$, only insolation and tidal range were retained for later modeling. The seven potential environmental variables were assembled to relate to bulk carbon in the sediments including tidal range, insolation, degree of sorting, relative wave energy, \%siltclay, mass in the sediment trap, and $\% \mathrm{~N}$ in the sediment trap. For the meadow sites, $\% \mathrm{~N}$ in eelgrass leave was also considered. Salinity was not included because the mean salinity range at our sites was low, most within 3 PSU. To reduce the possibility of multicollinearity, the correlation among variables was considered separately for the meadow (Table S2) and unvegetated (Table S3) sites. For the meadow sites, the six independent variables retained for inclusion in models were tidal range, insolation, degree of sorting \%siltclay, mass in the sediment trap, and $\% \mathrm{~N}$ in the sediment trap (Table S4). For the unvegetated sites, the four independent variables retained for inclusion in models were tidal range, relative wave energy, \%silt-clay, and mass in the sediment trap (Table S4). For the meadow sites, an additional set of models were constructed that included eelgrass morphology and growth. Because leaf area and growth were significantly correlated ( $r=0.667, p=0.0499)$, only growth was retained. Growth was also significantly correlated with $\% \mathrm{~N}$ in the sediment trap ( $r=-0.669, p=0.049$ ), while shoot density was significantly correlated with both insolation $(r=0.663, p=0$. 037) and mass in the sediment trap $(r=-0.808, p=0.005)$. The final meadow models with both environmental and eelgrass variables included five variables: tidal range, degree of sorting, \%silt-clay, shoot density, and growth (Table S4). Because Boston Harbor was missing both growth and sediment trap data, it was not included in any of these models.

Relative importance of individual variables was determined examining the sum of the weighted Akaike's information criterion ( $\mathrm{AIC} \omega$ ) for every model containing that variable (Burnham and Anderson 2002). IC $\omega$ are calculated as 
AIC $\omega=$ exp. $(-0.5 \times \Delta$ AIC individual model $) / \sum$ exp. $(-$ $0.5 \times \triangle \mathrm{AIC}$ all models) where $\triangle \mathrm{AIC}=\mathrm{AIC}$ individual model - AIC min. A final model average was obtained by multiplying the coefficients for a given model by the AIC $\omega$ for that model, and then averaging the resulting coefficients for a given variable across all models. To see if a more parsimonious model might be possible, a model using only the most important variables based on $\sum \mathrm{AIC} \omega$ was compared with the full model with all variables using the likelihood ratio statistic, $G^{2}$ (Agresti 1996). The best, most parsimonious submodel was selected that had a low AIC value and a non-significant $G^{2}$ test.

\section{Results}

\section{Eelgrass Morphology, Structure, and Growth}

Univariate comparisons using one-factor ANOVA showed significant differences among sites for structural, morphological, and growth characteristics (Fig. 2a, shoot density $F_{10,44}=44.4924, p<0.0001 ;$ Fig. $2 \mathrm{~b}$, leaf area $F_{10,246}=$ $42.773, p<0.0001$; Fig. 2c, growth $\mathrm{mg} /$ shoot/day $F_{8125}=$ $11.0637, p<0.0001 ;$ Fig. S3a, leaves/shoot $F_{10,246}=$ $11.1510, p<0.0001$; Fig. S3b, internode length $F_{10,241}=$ 19.8383, $p<0.0001$; Fig. S3c, aboveground-belowground weight $F_{10,245}=7.5289, p<0.0001$; Fig. S3d, growth $\mathrm{cm} /$ shoot/day $\left.F_{8125}=33.3469, p<0.0001\right)$. Cohasset Harbor had the highest shoot density while Boston Harbor and Prudence Island had the lowest (equivalent to Portland and Great Bay). Great Bay shoots had the greatest leaf areas (Fig. 2b), internode lengths (equivalent to Prudence Island; Fig. S3), and growth rates $\mathrm{cm} / \mathrm{shoot} / \mathrm{day}$ (equivalent to Portland; Fig. S3). Charlestown shoots had more leaves than all sites except Nahant (Fig. S3).

\section{Carbon Stocks}

Carbon depth profiles varied by site (Fig. 3). Distinct subsurface peaks were seen in Portland and Boston Harbor. Some declines in carbon density with depth were observed especially in meadow sites in Gloucester, Orleans, and Martha's Vineyard. Assessment of $\mathrm{C}_{\text {org }}$ stocks in this study were based on $\% \mathrm{C}$ from the IRMS output; however, we found a tight correlation between \%C from the IRMS and organic matter assessed using loss on ignition ( $\operatorname{adj} R^{2}=0.98$ ), allowing translation between methods (Fig. S4).

Sediment trap $C_{\text {org }}$ stocks ranged from 30 to $550 \mathrm{~g} \mathrm{C} / \mathrm{m}^{2}$ in meadows and from 70 to $500 \mathrm{~g} \mathrm{C} / \mathrm{m}^{2}$ in unvegetated areas. Significant differences were observed among sites $\left(F_{9,59}=\right.$ $179.78, p<0.0001$ ), among treatments (meadow vs unvegetated sites; $F_{9,59}=69.43, p<0.0001$ ), and a significant site per treatment effect $\left(F_{9,59}=23.93, p<0.0001\right)$. Most unvegetated sites had higher carbon $\left(\mathrm{g} \mathrm{C}^{2} \mathrm{~m}^{2}\right)$ in sediment traps in unvegetated areas than those in the meadow sites; only three meadow sites had higher carbon $\left(\mathrm{g} \mathrm{C}^{2} \mathrm{~m}^{2}\right)$ in sediment traps relative to traps located in unvegetated areas (Fig. S5).

$\mathrm{C}_{\text {org }}$ stocks in the upper $30 \mathrm{~cm}$ of the sediments ranged from 1500 to $4500 \mathrm{~g} \mathrm{C} / \mathrm{m}^{2}$ in meadows and from 100 to $5500 \mathrm{~g} \mathrm{C} / \mathrm{m}^{2}$ in unvegetated sites and were significantly different across sites $\left(F_{10,65}=84.76, p<0.0001\right)$ and treatments $\left(F_{1,65}=24.33, p<0.0001\right)$. There was also a significant site per treatment interaction $\left(F_{10,65}=15.78, p<0.0001\right)$; nine of the 11 sites had higher $\mathrm{C}_{\text {org }}$ stocks in sediment cores from meadows relative to those from unvegetated sites (Fig. 4). Portland, Great Bay, Boston Harbor, and Charlestown had the highest $\mathrm{C}_{\text {org }}$ stocks. The apparent north-south gradient in $\mathrm{C}_{\text {org }}$ stocks was statistically significant (Fig. 5).

Because of the lack of synoptically collected samples, we were not able to perform statistical analyses of the carbon stock in aboveground vegetation. However, based on visualizing the data, there were apparent differences among sites
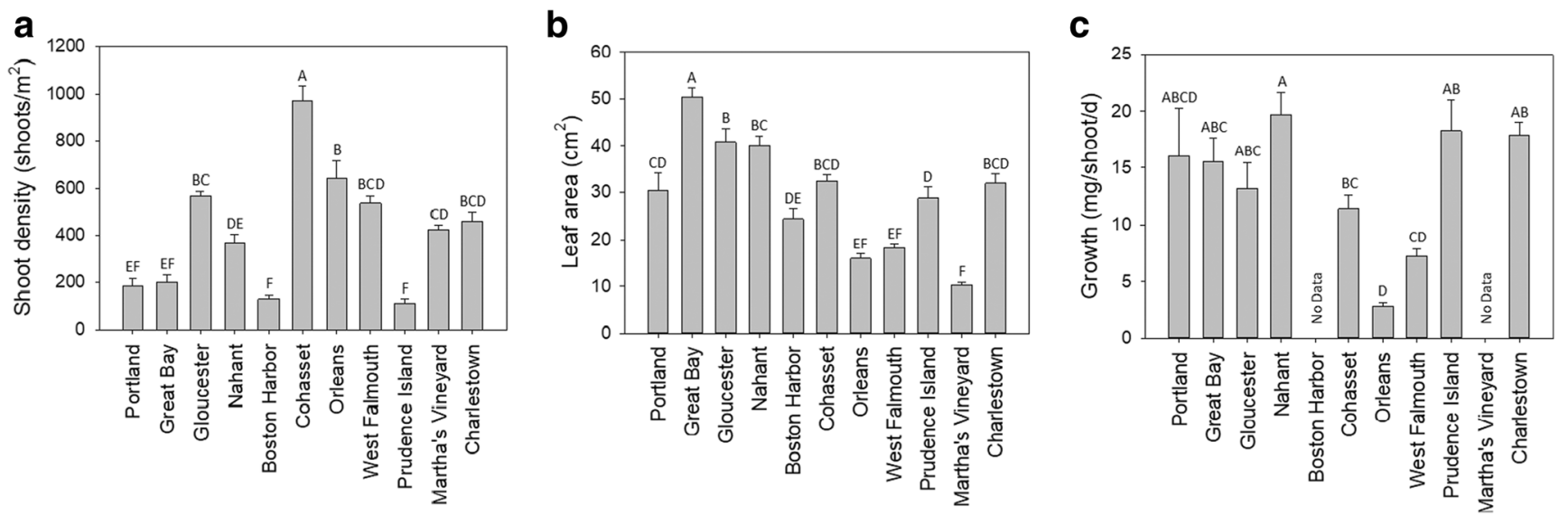

Fig. 2 Structural, morphological, and growth characteristics of eelgrass meadows. Letters indicate statistical differences among sites. a Shoot density $\left(\right.$ shoots $\left./ \mathrm{m}^{2}\right)$. b Leaf area $\left(\mathrm{cm}^{2}\right)$. c Growth $(\mathrm{mg} /$ shoot/day) 
a Portland

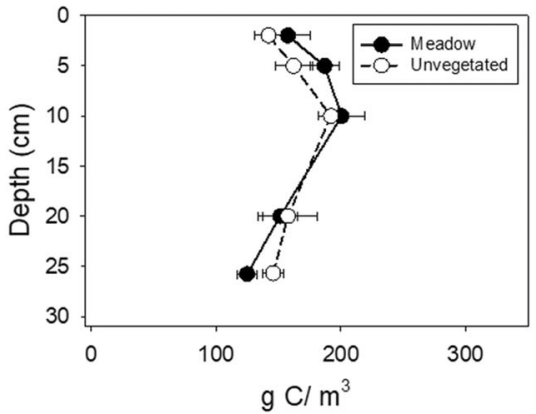

d

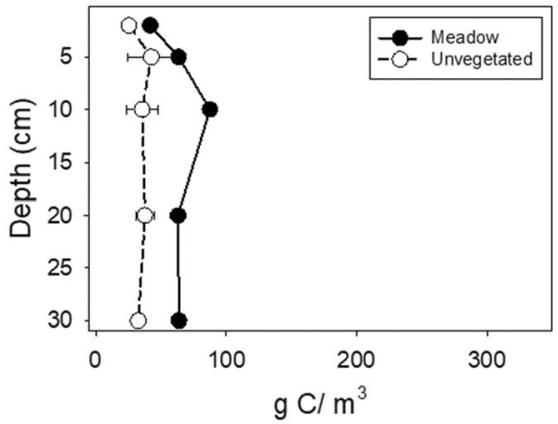

b

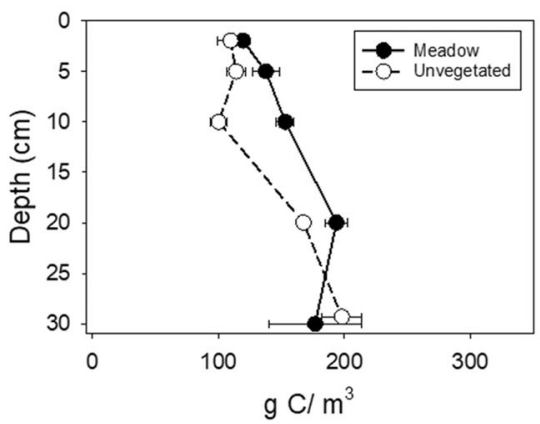

Boston Harbor

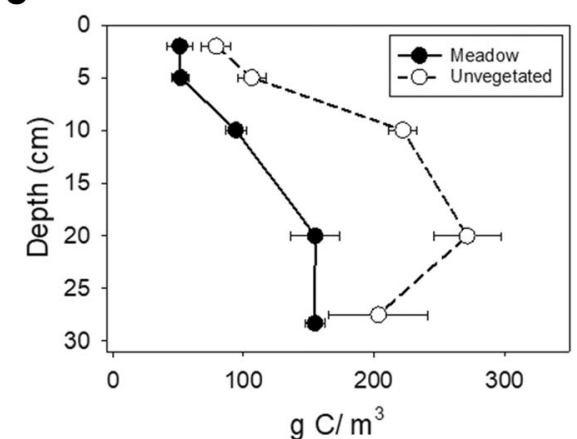

C

Gloucester

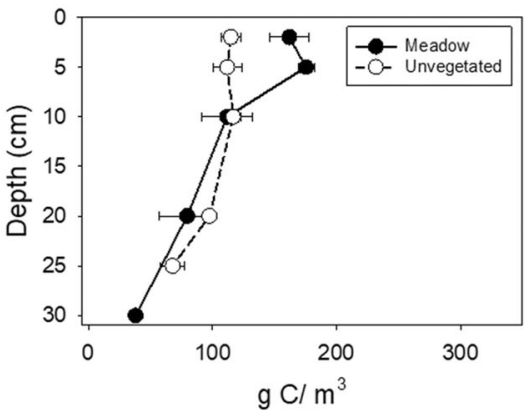

f

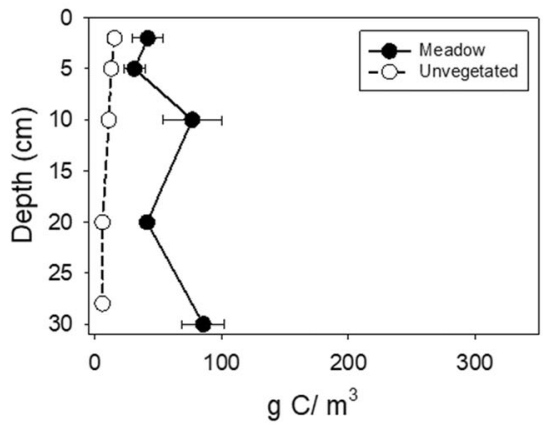

Fig. 3 Depth profiles of carbon density. Meadow sites are indicated by a closed black symbol and solid line, while the unvegetated sites are indicated by an open symbol and dotted line. a Portland, ME. b Great
Bay, NH. c Gloucester, MA. d Nahant, MA. e Boston Harbor, MA. f Cohasset, MA. g Orleans, MA. h West Falmouth, MA. i Prudence Island, RI. j Martha's Vineyard, MA. k Charlestown, RI

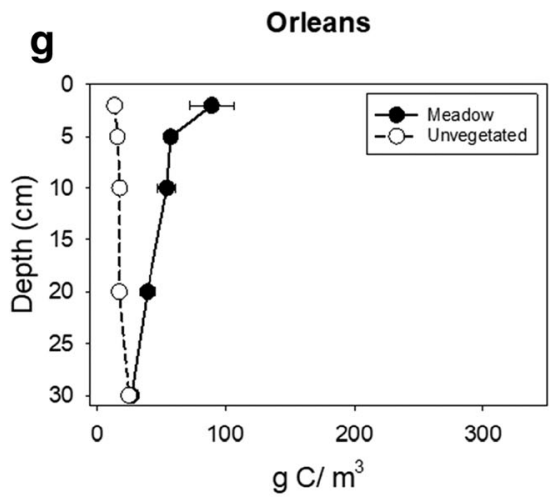

h

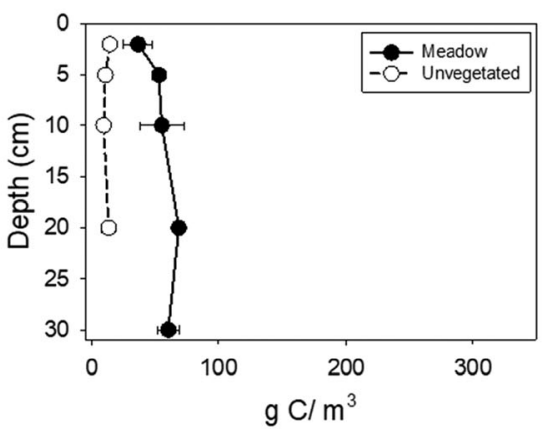

k

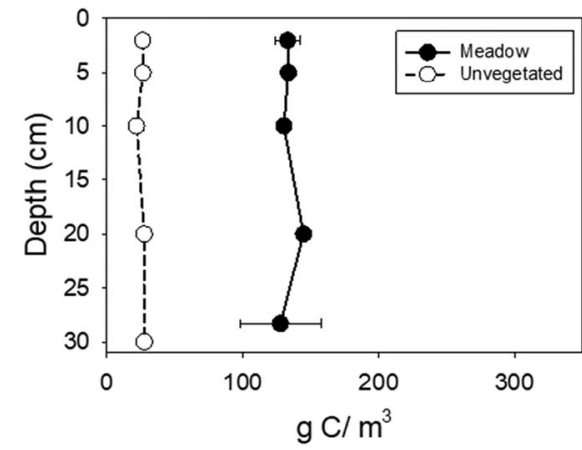

i

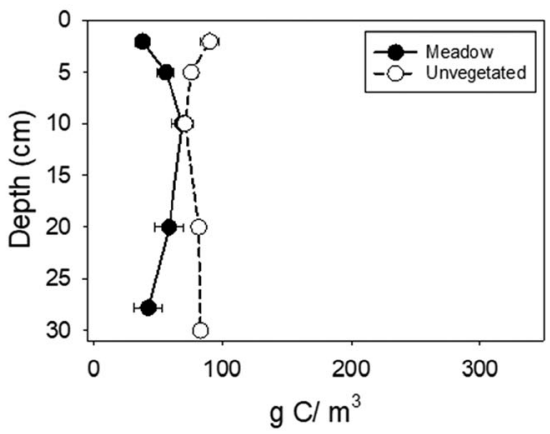

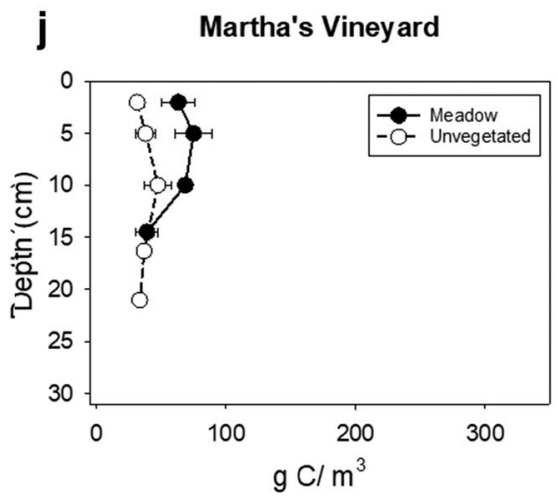

Fig. 3 continued. 
(Fig. 6), and there was no significant relationship between biomass carbon stocks and latitude $(p=0.897)$.

For the meadow sites, 126 possible models were generated between carbon stocks in the top $5 \mathrm{~cm}$ of the core and tidal range, insolation, degree of sorting, \%silt-clay contents, mass in the sediment trap, and \%N in the sediment trap. Sixty-two models were generated between carbon stocks in the top $5 \mathrm{~cm}$ of the core and tidal range, degree of sorting, \%silt-clay, shoot density, and growth. In the unvegetated areas, 30 models were generated between carbon stocks in the top $5 \mathrm{~cm}$ of the core and were tidal range, relative wave energy, \%silt-clay, and mass in the sediment trap.

The AIC $\omega$ for each model was used to calculate the relative importance of the individual variables. For meadow cores, only considering environmental variables, \%silt-clay had the highest importance $\left(\sum \mathrm{AIC \omega}=0.77\right)$ in predicting the $\mathrm{C}_{\text {org }}$ stocks in the top $5 \mathrm{~cm}$ of the core, while $\% \mathrm{~N}$ in the sediment trap had the next highest importance $\left(\sum \mathrm{AIC} \omega=0.39\right)$ and the remaining variables had lower importance (Table 2). When eelgrass variables were included, the pattern changed. Degree of sorting had the highest importance $\left(\sum \mathrm{AIC} \omega=0.82\right)$, shoot density also had high importance $\left(\sum \mathrm{AIC} \omega=0.74\right)$, \%silt-clay having moderate importance $\left(\sum \mathrm{AIC} \omega=0.44\right)$, and tidal range $\left(\sum \mathrm{AIC} \omega=\right.$ $0.16)$ and growth $\left(\sum \mathrm{AIC} \omega=0.12\right)$ had lower importance (Table 2). In the unvegetated areas, \%silt-clay had the highest importance $\left(\sum \mathrm{AIC} \omega=1.00\right)$, while the remaining variables had low importance in predicting the carbon stock in the top $5 \mathrm{~cm}$ of the core (Table 2).

The final averaged model based on environmental variables alone at meadow sites was able to significantly predict

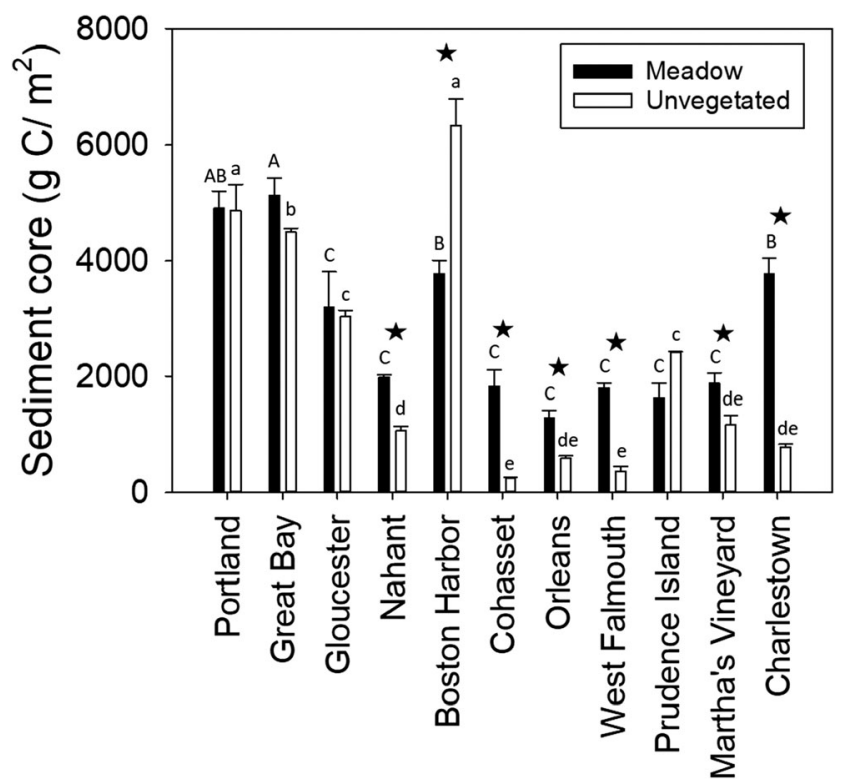

Fig. 4 Sediment carbon stock $\left(\mathrm{g} \mathrm{C}^{2} \mathrm{~m}^{2}\right)$ from cores collected in meadow and unvegetated areas. Capital letters indicate statistical differences among sites in meadows, while lowercase letters indicate statistical differences among sites in unvegetated areas. Stars indicate significant differences between meadow and unvegetated areas

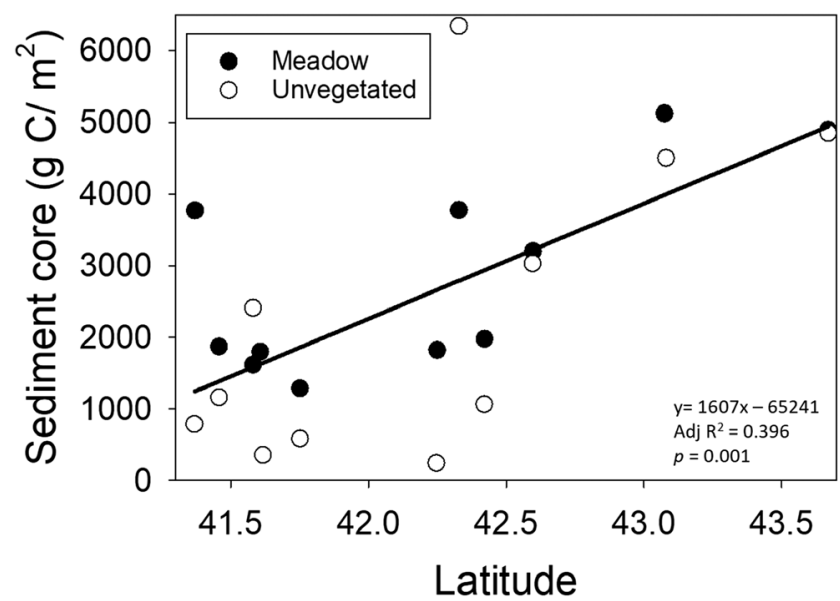

Fig. 5 Scatter plot showing significant increases in sediment carbon stocks with increasing latitude. The symbols represent the site mean for all 11 sites

$\left(\operatorname{adj} R^{2}=0.631, p=0.004\right)$ carbon stock in the top $5 \mathrm{~cm}$ of the core (Fig. 7a). When including eelgrass variables, predictive ability decreased $\left(\operatorname{adj} R^{2}=0.472\right)$ but was still significant $(p=$ 0.017; Fig. 7b). The final averaged model at unvegetated sites was also able to significantly predict $\left(\operatorname{adj} R^{2}=0.729, p=\right.$ 0.001 ) the carbon stock in the top $5 \mathrm{~cm}$ of the core (Fig. 7c). In the meadow sites, using only the variables with the highest importance (degree of sorting, shoot density, and \%silt-clay) resulted in a model that performed as well as the saturated model (tidal range, degree of sorting, \%silt-clay, shoot density, and growth) as indicated by a lower AIC value and nonsignificant $G^{2}$ test. However, the amount of variance explained was slightly lower $\left(\operatorname{adj} R^{2}=0.418\right)$, although still significant ( $p=0.026$; Fig. S6a). In the unvegetated areas, sediment grain size distribution alone could predict $\mathrm{C}_{\text {org }}$ stocks in the top $5 \mathrm{~cm}\left(\operatorname{adj} R^{2}=0.728, p=0.001\right)$ as well as the full

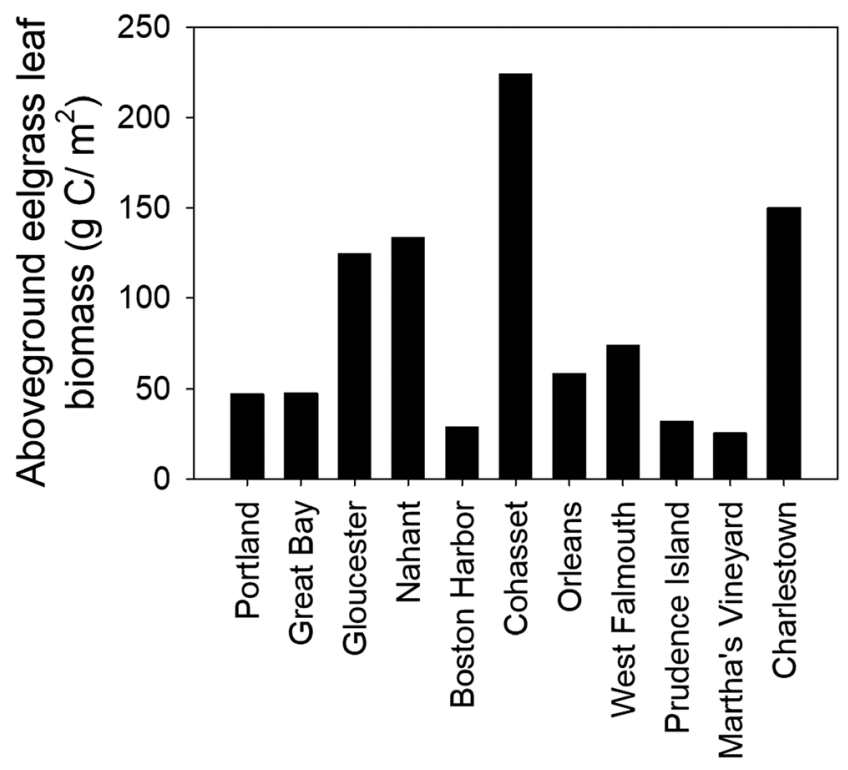

Fig. 6 Carbon stock ( $\mathrm{g} \mathrm{C} / \mathrm{m}^{2}$ ) of aboveground eelgrass across study sites 
Table 2 Importance of individual variables to predicting the carbon stock in the top $5 \mathrm{~cm}$ of the core. $\sum \mathrm{AIC} \omega$ near 1 indicate high importance while those near zero have low importance

\begin{tabular}{|c|c|c|c|c|}
\hline Model & $\sum \mathrm{AIC} \omega$ & Environmental variables only & $\sum \mathrm{AIC} \omega$ & Environmental and eelgrass variables \\
\hline \multirow[t]{6}{*}{ Meadow } & 0.77 & $\%$ Silt-clay & 0.82 & Degree of sorting \\
\hline & 0.39 & $\% \mathrm{~N}$ in sediment trap & 0.74 & Shoot density $\left(/ \mathrm{m}^{2}\right)$ \\
\hline & 0.28 & Degree of sorting & 0.44 & $\%$ Silt-clay \\
\hline & 0.27 & Tidal range $(\mathrm{m})$ & 0.16 & Tidal range $(\mathrm{m})$ \\
\hline & 0.25 & 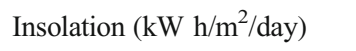 & 0.12 & Growth (mg/shoot/day) \\
\hline & 0.22 & Sediment trap mass $(\mathrm{g})$ & & \\
\hline \multirow[t]{4}{*}{ Unvegetated } & 1.00 & $\%$ Silt-clay & & N/A \\
\hline & 0.22 & Sediment trap mass $(\mathrm{g})$ & & \\
\hline & 0.22 & Tidal range $(\mathrm{m})$ & & \\
\hline & 0.16 & Relative wave energy & & \\
\hline
\end{tabular}

model (Fig. S6b), as indicated by a lower AIC value and nonsignificant $G^{2}$ test.

\section{Carbon Source, Carbon Accumulation, and Age of Cores}

Isotopic biplots were used to investigate the source of material to the sediments in the meadow (Fig. 8). Sediment trap material $\delta^{13} \mathrm{C}$ ranged from -22.13 to -
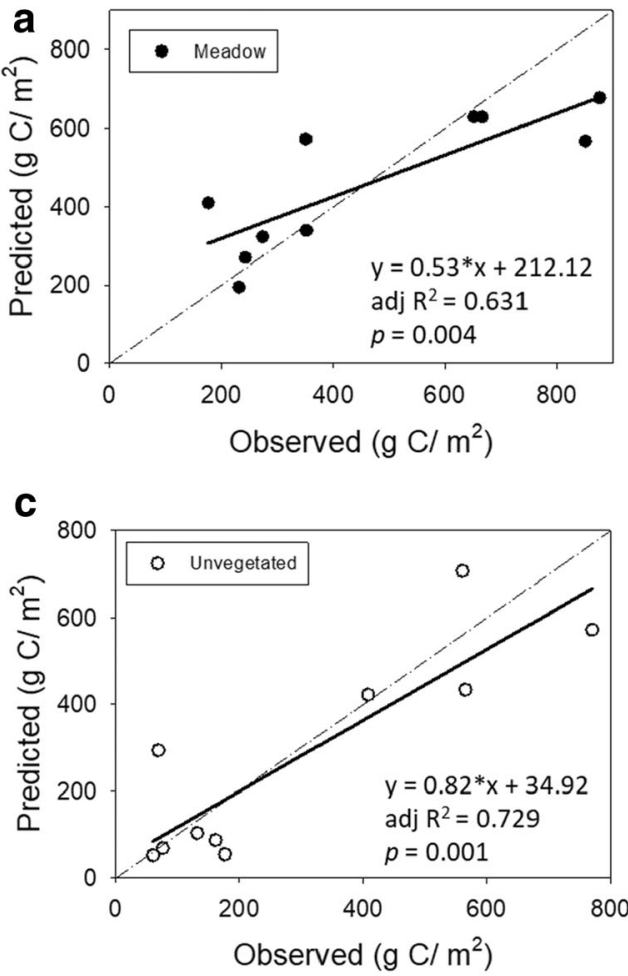

Fig. 7 Predicted $C_{\text {org }}$ stocks in sediments using environmental and eelgrass variables. The dashed line indicates a 1:1 relationship between the observed data and the modeled output. The solid line shows the regression line that best fits the predicted output. For the regression equation, $y=$ predicted bulk carbon $\left(\mathrm{g} \mathrm{C} / \mathrm{m}^{2}\right), x=$ observed bulk carbon $\left(\mathrm{g} \mathrm{C} / \mathrm{m}^{2}\right)$, and adj $R^{2}$ is the amount of variance explained after correcting for the number of parameters in the model. a Model output for top $5 \mathrm{~cm}$ of
$15.10 \%$, and $\delta^{13} \mathrm{C}$ values in sediment were similar to the sediment trap material, ranging from -22.93 to $14.86 \%$. $\delta^{15} \mathrm{~N}$ values of sediment trap material ranged from 5.78 to $9.13 \%$, while $\delta^{15} \mathrm{~N}$ in the sediment had a much broader range (3.90 to $17.81 \%$ ). Aboveground eelgrass had a much different isotopic signature than the sediment trap material or the sediment (Fig. 8). $\delta^{15} \mathrm{~N}$ of eelgrass ranged from 3.04 to $9.13 \% ; \delta^{13} \mathrm{C}$ ranged from 12.24 to $-6.26 \%$.

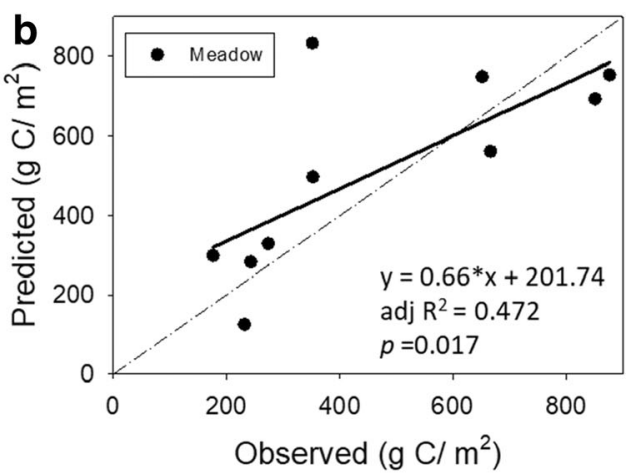

core in meadow, predicted using environmental variables only. The figure shows model average results based on 126 models and 10 sites. b Model output for top $5 \mathrm{~cm}$ of core in meadow, predicted using a combination of environmental and eelgrass variables. The figure shows model average results based on 62 models and 10 sites. $\mathbf{c}$ Model output for top $5 \mathrm{~cm}$ of core in unvegetated areas predicted using environmental variables only. The figure shows model average results based on 30 models and 10 sites 
Cores from Boston Harbor, West Falmouth, and Martha's Vineyard could not be dated with the ${ }^{210} \mathrm{~Pb}$ method because of either significant mixing or because sediment accumulation was too low or negligible. Great Bay showed the highest sedimentation and $\mathrm{C}_{\text {org }}$ accumulation rates $\left(1.19 \pm 0.15 \mathrm{~g} / \mathrm{cm}^{2} /\right.$ year and $230 \pm 30 \mathrm{~g} \mathrm{C}^{2} / \mathrm{m}^{2}$ year, respectively), over the dated period which encompassed the last two decades (18 years in the upper $30 \mathrm{~cm}$, Table 3$)$. This contrasts with the Gloucester, MA site that has the lowest sedimentation rate $(0.12 \pm 0.01 \mathrm{~g} /$ $\mathrm{cm}^{2} /$ year) and Orleans or Prudence, which showed the lowest $\mathrm{C}_{\text {org }}$ accumulation rates $\left(8-9 \mathrm{~g} \mathrm{C} / \mathrm{m}^{2} /\right.$ year $)$ in the upper $30 \mathrm{~cm}$ of the core over the last century (Table 3 ).

\section{Discussion}

Eelgrass is the most wide-ranging seagrass species in the Northern Hemisphere and provides important ecosystem services to coastal environments. Recent studies have shown significant variation in estimates of carbon stocks $\left(\mathrm{C}_{\text {org }}\right.$ stocks) and carbon accumulation rates ( $\mathrm{C}_{\text {org }}$ accumulation) in seagrass meadows, suggesting that more information is needed to understand the factors influencing variability (Fourqurean et al. 2012; Lavery et al. 2013; Röhr et al. 2018). In our study, we estimated $\mathrm{C}_{\text {org }}$ stocks and $\mathrm{C}_{\text {org }}$ accumulation at 11 eelgrass meadows across New England, representing a range of eutrophication and exposure conditions. In addition, we identified the environmental factors and structural characteristics of meadows related to variation in $\mathrm{C}_{\text {org }}$ stocks. Our results show large variation in $\mathrm{C}_{\text {org }}$ stocks and $\mathrm{C}_{\text {org }}$ accumulation across New England eelgrass meadows (Table 4).

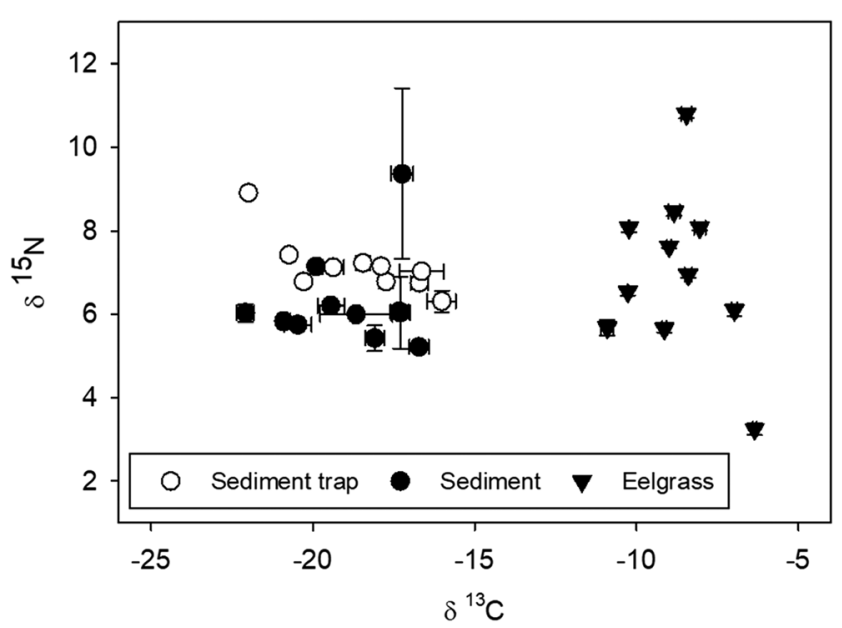

Fig. 8 Biplot showing isotopic signal of material from sediment traps, sediment from cores and aboveground eelgrass. The symbol is the mean value while the error bars are standard errors

\section{Carbon Stocks in Eelgrass Meadows}

Overall most of the New England eelgrass meadows in this study had higher sediment $\mathrm{C}_{\text {org }}$ stocks than nearby unvegetated areas (Fig. 4), supporting previous studies that indicate seagrass ecosystems are a significant carbon sink (Fourqurean et al. 2012; Röhr et al. 2018). The exceptions were primarily at sites with higher nutrients, where allochthonous carbon accumulated in both meadow and unvegetated sediments equally. The average sediment $C_{\text {org }}$ stock in the upper $30 \mathrm{~cm}$ for eelgrass in New England ( $2832 \pm 416 \mathrm{~g} \mathrm{C} / \mathrm{m}^{2}$ ) was comparable to worldwide estimates for eelgrass ( $2721 \pm 989 \mathrm{~g} \mathrm{C} / \mathrm{m}^{2}$; Röhr et al. 2018), but lower than global estimates that include all seagrass species $\left(19,420 \pm 202 \mathrm{~g} \mathrm{C} / \mathrm{m}^{2}\right.$; Fourqurean et al. 2012; Table 4). The highest $\mathrm{C}_{\text {org }}$ stocks occurred in Portland Harbor and Great Bay eelgrass meadows. At both sites, sediment $\mathrm{C}_{\text {org }}$ stocks were twice as high as worldwide estimates for eelgrass and three times as high as the average $C_{\text {org }}$ stocks for eelgrass meadows in the Atlantic Ocean, Pacific Ocean, Baltic Sea, and Black Sea (Röhr et al. 2018). However, this was also the case for their concurrent bare analogues, suggesting that $\mathrm{C}_{\text {org }}$ storage at these sites is driven by local nutrient loading and depositional environment. In addition to having high $\mathrm{C}_{\text {org }}$ stocks, meadows in Portland Harbor, Great Bay, as well as Charlestown had the highest $\mathrm{C}_{\text {org }}$ accumulation rates. Excluding sites with higher nutrients, eelgrass $\mathrm{C}_{\text {org }}$ stocks were highest in Charlestown, being two times higher than average $\mathrm{C}_{\text {org }}$ stocks found in temperate eelgrass meadows globally (Röhr et al. 2018). Carbon content in aboveground biomass was also estimated at each site and the average $\left(86 \pm 19 \mathrm{~g} \mathrm{C} / \mathrm{m}^{2}\right)$ for New England was comparable to estimates for all species in the Temperate North Atlantic Bioregion (Table 4; i.e., Ruppia maritima, Z. marina, Z. noltii, Cymodocea nodosa, and Halodule wrightii; Short et al. 2007; Fourqurean et al. 2012).

\section{Factors Influencing C Stocks}

Our study was initiated under the assumption that differences in eutrophication and exposure would be reflected in the amount of carbon stored within eelgrass meadows. The results provided some support for the role of these parameters in carbon storage. Our multimodel inference model using environmental variables showed that $\%$ nitrogen in sediment traps was of secondary importance in eelgrass meadows (Table 2). In addition, sites with the highest nutrient levels (Portland, Great Bay) had the highest $C_{\text {org }}$ stocks in both meadow and unvegetated areas (Table 1; Fig. 4). Other studies have also shown that nutrient inputs can influence carbon storage and accumulation in seagrass meadows as well as in unvegetated sediments due to an increase in the rate of organic matter supplied to the system (Gacia et al. 2002; Mazarrasa et al. 2017; Samper-Villarreal et al. 2017; Kindeberg et al. 2018). Moreover, increasing organic matter can influence 
Table 3 Sediment accumulation and carbon accumulation based on $210 \mathrm{~Pb}$ modeling from sediment cores. In some cases (Portland, Nahant), sedimentation uncertainties in the model did not allow a definitive core date to be defined rates could be determined, but

\begin{tabular}{lllll}
\hline Site & Site code & $\begin{array}{l}\text { Sediment accumulation } \\
\text { rate }\left(\mathrm{g} / \mathrm{cm}^{2} / \text { year }\right)\end{array}$ & $\begin{array}{l}\text { Carbon accumulation } \\
\text { rate }\left(\mathrm{g} \mathrm{C} / \mathrm{m}^{2} / \text { year) }\right.\end{array}$ & Core age (year) \\
\hline Portland, ME & PO & $0.16 \pm 0.09$ & $48 \pm 25$ & No data $^{\mathrm{c}}$ \\
Great Bay, NH & GB & $1.19 \pm 0.15$ & $230 \pm 30$ & 18 \\
Gloucester, MA & NB & $0.121 \pm 0.008$ & $16.7 \pm 1.1$ & 113 \\
Nahant, MA & PC & $0.29 \pm 0.08$ & $20 \pm 5$ & No data $^{\mathrm{c}}$ \\
Boston Harbor, MA & BH & No data $^{\mathrm{a}}$ & No data $^{\mathrm{a}}$ & No data $^{\mathrm{a}}$ \\
Cohasset, MA & CT & No data $^{\mathrm{a}}$ & No data & No data \\
Orleans, MA & PB & $0.27 \pm 0.08$ & $8 \pm 2$ & 95 \\
W. Falmouth, MA & WF & No data & No data \\
Prudence Island, RI & PI & $0.14 \pm 0.02$ & No data & 113 \\
Martha's Vineyard, MA & MV & No data $^{\mathrm{a}}$ & $8.9 \pm 1.2$ & No data \\
Charlestown, RI & NP & $0.26 \pm 0.03$ & No data & 54 \\
\hline
\end{tabular}

${ }^{\text {a }}$ Signs of disturbance/mixing in profile

${ }^{\mathrm{b}}$ Sediment accumulation low or negligable

${ }^{\mathrm{c}}$ Age could not be calculated

morphology and structure of eelgrass meadows so that carbon is more effectively trapped (Short and Kaldy 1995). Eelgrass collected from Great Bay for our study appears to have responded to excess nitrogen in the system with increased leaf area (Fig. 2). However, we expect that as nitrogen loading increases, plant productivity and survival will decrease along with storage (Schmidt et al. 2012; Macreadie et al. 2017; Jiang et al. 2018).

Our results also show that exposure is an important predictor of carbon storage in eelgrass meadows. The model that included both environmental and eelgrass variables to evaluate importance in meadows indicated that degree of sorting was the most important variable and was positively correlated with bulk carbon stocks. Exposure affects carbon storage through the balance of accumulation and export (Mazarrasa et al. 2018). The sites in this study have carbon sources from primarily outside the meadow, suggesting that degree of sorting in this study can be used as a measure of input of material to the site. Röhr et al. (2018) also showed positive relationships between degree of sorting and carbon stocks worldwide.
Our study identified additional environmental and plant parameters that influence $\mathrm{C}_{\text {org }}$ stocks. Multimodel inference showed that \%silt-clay was the most important predictor of $\mathrm{C}_{\text {org }}$ stocks in sediment in both meadow and unvegetated sites when considering environmental variables alone. When assessing environmental and eelgrass variables in meadows, \%silt-clay was still important, but was overpassed by the degree of sorting (Table 2). Results from this study support previous studies that show a positive relationship between fine-grained sediments and $\mathrm{C}_{\text {org }}$ stocks (e.g., Dahl et al. 2016; Röhr et al. 2016; Mazarrasa et al. 2017; Oreska et al. 2017; Röhr et al. 2018): sites with the highest $C_{\text {org }}$ stocks (Portland, Great Bay, Boston Harbor, and Charlestown) were comprised of silt or very fine sand (Table 1; Fig. 4). The relationship between carbon storage and fine-grained sediments can be attributed to the larger surface area for adsorbing organic molecules (Bergamaschi et al. 1997) and anoxic conditions in the substrate, which allows carbon and nutrients to accumulate in soil (Koch 2001). Others have suggested that hydrodynamic regime can also explain this relationship as
Table 4 Comparison of carbon inventory from this study to other areas

\begin{tabular}{|c|c|c|c|c|}
\hline Study & Geographic area & Seagrass type & $\begin{array}{l}\text { Seagrass } \\
\text { aboveground } \\
\mathrm{C}\left(\mathrm{g} \mathrm{C}^{2} \mathrm{~m}^{2}\right)\end{array}$ & $\begin{array}{l}\text { Sediment } \\
\qquad \mathrm{C}\left(\mathrm{g} \mathrm{C}^{2} \mathrm{~m}^{2}\right)\end{array}$ \\
\hline \multirow[t]{2}{*}{ Fourqurean et al. $(2012)^{\mathrm{a}}$} & Worldwide & All species & $251 \pm 49$ & $19,420 \pm 202$ \\
\hline & North Athlantic & All species & $85 \pm 19$ & $4870 \pm 1450$ \\
\hline Röhr et al. (2018) & $\begin{array}{l}\text { Worldwide } \\
\text { Western Atlantic }\end{array}$ & $\begin{array}{l}\text { Zostera } \\
\quad \text { marina } \\
\text { Zostera } \\
\quad \text { marina }\end{array}$ & & $\begin{array}{l}2721 \pm 989 \\
1349 \pm 2\end{array}$ \\
\hline This study $^{\mathrm{b}}$ & $\begin{array}{c}\text { Northwestern } \\
\text { Atlantic }\end{array}$ & $\begin{array}{l}\text { Zostera } \\
\quad \text { marina }\end{array}$ & $86 \pm 19$ & $2832 \pm 416$ \\
\hline
\end{tabular}

${ }^{\text {a }}$ Reported as mean $\pm 95 \%$ confidence interval

${ }^{\mathrm{b}}$ Reported as mean \pm standard error 
grain size composition of sediments is largely controlled by wave and current exposure (Mazarrasa et al. 2017; Kindeberg et al. 2018). In our study, this is supported by meadows at Charlestown where the two predictors (fine grain sediments, and low hydrodynamic energy) converge resulting in the largest eelgrass derived $C_{\text {org }}$ stocks (Table 1 ).

An interesting outcome of this study is the importance of commonly measured environmental variables in predicating carbon storage in meadows, as well as unvegetated sites. In unvegetated sites, \%silt-clay explained $73 \%$ of the variance in surface carbon stocks (Fig. S6b) and was not significantly different from a model including sediment trap mass, tidal range and relative wave energy. In contrast, the meadow models with environmental and eelgrass variables explained less of the variance in carbon stocks than models using environmental variables alone (Fig. 7). The difference in explained variance may be due to inclusion of variables impacting meadow health such as tidal range and insolation. It is also possible that more of the variance could have been explained if we had good measures of light attenuation (reduction in the intensity of light as it travels through water) rather than insolation (the amount of light reaching the surface of the water).

\section{Sources of Carbon to Seagrass Meadows}

Numerous studies have reported higher $\mathrm{C}_{\text {org }}$ accumulation rates for seagrass sediments than predicted from plant production alone, indicating that allochthonous sources contribute to seagrass sediment $C_{\text {org }}$ stocks (Bouillon and Boschker 2006; Kennedy et al. 2010). Kennedy et al. (2010) predicted that $50 \%$ of $\mathrm{C}_{\text {org }}$ in seagrass sediments was of autochthonous origin. In our study, the isotope biplot suggested that eelgrass was not the dominate source of carbon in the sediment (Fig. 8). Röhr et al. (2018) found similar results in the western Atlantic where Zostera contributed approximately 10-40\% of the carbon stock. Great Bay, Boston Harbor, and Portland have the highest $\mathrm{C}_{\text {org }}$ stocks, and relatively high percentage of fine-grained sediments $(35 \%, 32 \%$, and $28 \%$ silt-clay, respectively). However, carbon inputs to the sediments are mostly allochthonous, possibly from terrestrial processes such as sewage discharges and tributaries and/or lower water exchange with the overlying water (Koch 2001), which leads to lower oxygen concentrations that slow the decomposition rate of accumulated carbon. The other site with relatively high $\mathrm{C}_{\text {org }}$ stocks in the meadow, Charlestown, had a high percentage of fine-grained sediments (42\%). While fine-grained sediments will most effectively bind $\mathrm{C}_{\text {org }}$ and reduce decomposition rates, eelgrass roots and rhizomes also have a high proportion of refractory organic compounds, and high $\mathrm{C} / \mathrm{N} / \mathrm{P}$ ratios, which makes them more resistant to degradation, relative to most marine plants and algae (Fourqurean and Schrlau 2003; Vichkovitten and Holmer 2004; Kennedy et al. 2009).

\section{Implications of Research}

The 2017 Update of the Regional Climate Change Action Plan for the New England States and Eastern Canada Provinces (https://www.coneg.org/wp-content/uploads/ transferred/Data/Sites/1/media/documents/reports/2017rccap-final.pdf) recognizes the importance of preserving and enhancing Blue Carbon reservoirs (carbon stored in coastal mangrove, marsh and eelgrass ecosystems) to achieve $\mathrm{CO}_{2}$ emission reduction goals. There is little site-specific carbon sequestration data available for New England. Our data has significant value in understanding worldwide carbon budgets as well as providing input for specific region issues.

Our study also confirmed the importance of local site characteristics highlighted by other studies (Dahl et al. 2016; Jankowska et al. 2016; Macreadie et al. 2014; Mazarrasa et al. 2017, 2018; Oreska et al. 2017; Röhr et al. 2016, 2018; Samper-Villarreal et al. 2016; Serrano et al. 2016b). Most sites in this study showed the expected pattern of higher carbon stocks in meadow versus unvegetated sediments. However, at sites experiencing higher eutrophication (e.g., Portland, Great Bay), this pattern was not seen, likely because these areas are depositional, with the amount of carbon stored in the sediments driven primarily by allochthonous loading rather than by meadow characteristics. Depositional areas are known to bury carbon, although the predicted storage rate in seagrass meadows is estimated to be twice that of estuarine sediments (Duarte et al. 2005). However, the importance of blue carbon arises not only from the ability of vegetated habitats to enhance carbon storage, but also by their ability to avoid emissions from disturbed sediments (Arias-Ortiz et al. 2018b; Macreadie et al. 2018). Therefore, the importance of the high carbon storage seen in Portland and Great Bay will hinge on its stability. During the growing season, meadow vegetation alters flow and stabilizes sediments. In New England winters, eelgrass meadows senesce but because their belowground roots and rhizomes are resistant to decomposition (Mcleod et al. 2011; Dahl et al. 2016), they act to stabilize the sediments. In contrast, the unvegetated areas may be more at risk for resuspension and erosion, leading to carbon oxidation and $\mathrm{CO}_{2}$ release unless stabilized by macrophytes or tubebuilding invertebrates. Without further research to understand if this unvegetated sediment has been stabilized, it should be viewed as vulnerable to oxidation.

Loss of seagrass is predicted to result in oxidation of stored carbon, resulting in $\mathrm{CO}_{2}$ emissions. While previous studies have assumed $100 \%$ oxidation, more recent studies predict a $10-50 \%$ loss of carbon in the top meter of sediments (Lovelock et al. 2017; Arias-Ortiz et al. 2018b). In addition, the probability of $\mathrm{CO}_{2}$ release from areas with seagrass loss will be dependent on both the amount of carbon stored in the sediment and the probability of carbon mineralization due to oxidation (Lovelock et al. 2017) so preservation of existing 
meadows should be prioritized. Once eelgrass meadows are lost, decreased sediment stability, increased turbidity, decreased water clarity, and increased phytoplankton blooms can decrease the probability of natural eelgrass recovery (Unsworth et al. 2015). Disturbances should be minimized as they can adversely impact seagrass and decrease carbon storage (Baraňano et al. 2018; Macreadie et al. 2015; Serrano et al. 2016a, b; Trevathan-Tackett et al. 2017b). However, restoration or regrowth of seagrass has been shown to restore the meadow's capacity for carbon storage (Macreadie et al. 2015; Marba et al. 2015). Given that eelgrass seeds are only viable for 1 year (Jarvis and Moore 2010; Orth et al. 2000), and the plants have specific water quality requirements (Dennison et al. 1993), additional management actions to stabilize the sediment and reintroduce seagrass may be needed to reestablish existing beds. This study also suggests that measurement of environmental variables that impact both seagrass meadow persistence and carbon storage may be a useful proxy to predict carbon stores.

Acknowledgments We would like to thank Fred Short, Eric Nelson, Dan Arsenault, Jean Brochi, Chuck Protzmann, Tim Bridges, Holly Plaisted, Agnes Mittermayr, Jill Carr, Tay Evans, Jack Buckley, Dani Ewart, Dave Grunden, Hanna Mogensen, Juliette Williams, Lindsay Peter, Audrey Michniak, Molly Sullivan, Ivy Mlsna, Kathryn Baltes, Bill Osbahr, and Don Cobb for their insights as well as assistance in the laboratory and field. We would also like to thank Mark Cantwell, Autumn Oczkowski, and Cathy Wigand for their technical reviews. AAO was supported by a PhD scholarship from Obra Social "LaCaixa" (LCF/BQ/ES14/ 10320004). This work is contributing to the ICTA "Unit of Excellence" (MinECo, MDM2015-0552). The IAEA is grateful for the support provided to its Environment Laboratories by the Government of the Principality of Monaco. The views expressed in this manuscript are those of the authors and do not necessarily represent the views or policies of the US Environmental Protection Agency. Any mention of trade names, products, or services does not imply an endorsement by the US government or the US Environmental Protection Agency. The EPA does not endorse any commercial products, services, or enterprises. This is STICS ORD-030640.

Funding Information Funding was provided to PM by the Generalitat de Catalunya (MERS 2017 SGR-1588) and an Australian Research Council LIEF Project (LE170100219).

Open Access This article is licensed under a Creative Commons Attribution 4.0 International License, which permits use, sharing, adaptation, distribution and reproduction in any medium or format, as long as you give appropriate credit to the original author(s) and the source, provide a link to the Creative Commons licence, and indicate if changes were made. The images or other third party material in this article are included in the article's Creative Commons licence, unless indicated otherwise in a credit line to the material. If material is not included in the article's Creative Commons licence and your intended use is not permitted by statutory regulation or exceeds the permitted use, you will need to obtain permission directly from the copyright holder. To view a copy of this licence, visit http://creativecommons.org/licenses/by/4.0/.

\section{References}

Agresti, A. 1996. An introduction to categorical data analysis. New York: John Wiley \& Sons.

Appleby, P.G., and F. Oldfield. 1978. The calculation of ${ }^{210} \mathrm{~Pb}$ dates assuming a constant rate of supply of unsupported $210 \mathrm{~Pb}$ to the sediment. Catena 5 (1): 1-8.

Arias-Ortiz, A., P. Masqué, J. Garcia-Orellana, O. Serrano, I. Mazarrasa, N. Marbà, C. Lovelock, P. Lavery, and C.M. Duarte. 2018a. Reviews and syntheses: ${ }^{210} \mathrm{~Pb}$-derived sediment and carbon accumulation rates in vegetated coastal ecosystems - setting the record straight. Biogeosciences 15 (22): 6791-6818.

Arias-Ortiz, A., O. Serrano, P. Masque, P.S. Lavery, U. Mueller, G.A. Kendrick, M. Rozaimi, A. Esteban, J.W. Fourqurean, N. Marba, M.A. Mateo, K. Murray, M.J. Rule, and C.M. Duarte. 2018b. A marine heat wave drives massive losses from world's largest seagrass carbon stocks. Nature Climate Change 8 (4): 338-344.

Armitage, A.R., and J.W. Fourqurean. 2016. Carbon storage in seagrass soils: long term nutrient history exceeds the effects of near-term nutrient enrichment. Biogeosciences 13 (1): 313-321.

Baraňano, C., E. Fernandez, and G. Mendez. 2018. Clam harvesting decreases the sedimentary carbon stock of a Zostera marina meadow. Aquatic Botany 146: 48-57.

Bergamaschi, B., E. Tsamakis, R. Keil, T. Eglinton, B.D. Montluçon, and J.I. Hedges. 1997. The effect of grain size and surface area on organic matter, lignin and carbohydrate concentration, and molecular compositions in Peru Margin sediments. Geochimica et Cosmochimica Acta 71 (6): 1247-1260. https://doi.org/10.1016/ S0016-7037(96)00394-8.

Bouillon, S., and H.T.S. Boschker. 2006. Bacterial carbon sources in coastal sediments: A cross-system analysis based on stable isotope data of biomarkers. Biogeosciences 3 (2): 175-185.

Burnham, K.P., and D.R. Anderson. 2002. Model selection and multimodel inference: a practical information-theoretic approach. 2nd ed. New York: Springer-Verlag.

Chmura, G.L., S.C. Anisfeld, D.R. Cahoon, and J.C. Lynch. 2003. Global carbon sequestering in tidal, saline wetland soils. Global Biogeochemical Cycles 17 (4): 1111. https://doi.org/10.1029/ 2002 GB001917.

Dahl, M., D. Deyanova, S. Gutschow, M.E. Asplund, L.D. Lyimo, V. Karamfilov, R. Santos, M. Björk, and M. Gullström. 2016. Sediment properties as important predictors of carbon storage in Zostera marina meadows: a comparison of four European areas. PLoS One 11 (12): e0167493.

Dennison, W.C., R.J. Orth, K.A. Moore, J.C. Stevenson, V. Carter, S. Kollar, P.W. Bergstrom, and R.A. Batiuk. 1993. Assessing water quality with submersed aquatic vegetation. BioScience 43 (2): 86 94.

Duarte, C.M., J.J. Middelburg, and N. Caraco. 2005. Major role of marine vegetation on the oceanic carbon cycle. Biogeosciences 2 (1): 1-8.

Enriquez, S., C.M. Duarte, and K. Sandjensen. 1993. Patterns in decomposition rates among photosynthetic organisms: the importance of detritus C:N:P content. Oecologia 94 (4): 457-471.

Folk, R.L., and W.C. Ward. 1957. A study in the significance of grainsize parameters. Journal of Sedimentary Petrology 27 (1): 3-26.

Fonseca, M.S., and A. Malhotra. 2010. WEMo (wave exposure model) user manual, version 4. Beaufort, NC: NOAA National Centers for Coastal Ocean Sciences.

Fourqurean, J.W., and E. Schrlau. 2003. Changes in nutrient content and stable isotope ratios of $\mathrm{C}$ and $\mathrm{N}$ during decomposition of seagrasses and mangrove leaves along a nutrient availability gradient in Florida Bay, USA. Chemistry and Ecology 19 (5): 373-390. https://oi.org/ 10.1080/02757540310001609370.

Fourqurean, J.W., C.M. Duarte, H. Kennedy, N. Marbà, M. Holmer, M.A. Mateo, E.T. Apostolaki, G.A. Kendrick, D. Krause-Jensen, 
K.J. McGlathery, and O. Serrano. 2012. Seagrass ecosystems as a globally significant carbon stock. Nature Geoscience 5 (7): 505 509 .

Gacia, E., and C.M. Duarte. 2001. Sediment retention by a Mediterranean Posidonia oceanica meadow: the balance between deposition and resuspension. Estuarine, Coastal and Shelf Science 52 (4): 505-514.

Gacia, E., C.M. Duarte, J.J. Middelburg. 2002. Carbon and nutrient deposition in a Mediterranean seagrass (Posidonia oceanica ) meadow, Limnology and Oceanography, 1. https://doi.org/10.4319/lo.2002. 47.1.0023

Gillis, L.G., F.E. Belshe, A.D. Ziegler, and T.J. Bouma. 2017. Driving forces of organic carbon spatial distribution in the tropical seascape. Journal of Sea Research 120: 35-40.

Green, E.P., and F.T. Short. 2003. World atlas of seagrasses. Berkeley: University of California Press.

Greiner, J.T., K.J. McGlathery, J. Gunnell, and B.A. McKee. 2013. Seagrass restoration enhances "blue carbon" sequestration in coastal waters. PLoS One 8 (8): e 72469.

Gullström, M., L.D. Lyimo, M. Dahl, G.S. Samuelsson, M. Eggertsen, E. Anderberg, L.M. Rasmusson, H.W. Linderholm, A. Knudby, S. Bandeira, L.M. Nordlund, and M. Björk. 2018. Blue carbon storage in tropical seagrass meadows relates to carbonate stock dynamics, plant-sediment processes, and landscape context: Insights from the Western Indian Ocean. Ecosystems 21 (3): 551-566.

Harlin, M.M., and B. Thorne-Miller. 1981. Nutrient enrichment of seagrass beds in a Rhode Island coastal lagoon. Marine Biology 65 (3): 221-229.

Howard, J., S. Hoyt, K. Isensee, M. Telszewki, and E. Pidgeon. 2014. Coastal blue carbon: methods for assessing carbon stocks and emissions factors in mangroves, tidal salt marshes, and seagrasses. Arlington: Conservation International, Intergovernmental Oceanographic Commission of UNESCO, International Union for Conservation of Nature.

Howard, J.L., A. Perez, C.C. Lopes, and J.W. Fourqurean. 2016. Fertilization changes seagrass community structure but not blue carbon storage: results from a 30-year field experiment. Estuaries and Coasts 39 (5): 1422-1434.

IPCC. 2018. (Intergovernmental Panel on Climate Change). Framing and context. In Special Report: Global Warming of $1.5{ }^{\circ} \mathrm{C}$, ed. V. Masson-Delmotte, P. Zhai, H.O. Pörtner, D. Roberts, J. Skea, P.R. Shukla, A. Pirani, W. Moufouma-Okia, C. Péan, R. Pidcock, S. Connors, J.B.R. Matthews, Y. Chen, X. Zhou, M.I. Gomis, E. Lonnoy, T. Maycock, M. Tignor, and T. Waterfield. Geneva: World Meteorological Organization.

Jankowska, E., L.N. Michel, A. Zaborska, and M. WłodarskaKowalczuk. 2016. Sediment carbon sink in low-density temperate eelgrass meadows (Baltic Sea). JGR Biogeosciences 121: 29182934.

Jarvis, J.C., and K.A. Moore. 2010. The role of seedlings and seed bank viability in the recovery of Chesapeake Bay, USA Zostera marina populations following a large-scale decline. Hydrobiologica 649 (1): 55-68.

Jiang, Zhijian, S. Liu, J. Zhang, Y. Wu, C. Zhao, Z. Lian, and X. Huang. 2018. Eutrophication indirectly reduced carbon sequestration in a tropical seagrass bed. Plant and Soil 426 (1-2): 135-152. https:// doi.org/10.1007/s11104-018-3604.

Kennedy, H., M. Björk, and M. 2009. Seagrass meadows. In The Management of Natural Coastal Carbon Sinks, ed. D. Laffoley and G. Grimsditch, 23-29. Gland: IUCN.

Kennedy, H., J. Beggins, C.M. Duarte, J.W. Fourqurean, M. Holmer, N. Marbà, and J.J. Middelburg. 2010. Seagrass sediments as a global carbon sink: isotopic constraints. Global Biogeochemical Cycles 24: 4.

Kindeberg, T., S. Ørberg, E. Röhr, M. Holmer, and D. Krause-Jensen. 2018. Sediment stocks of carbon, nitrogen, and phosphorus in
Danish eelgrass meadows. Frontiers in Marine Science 5: 1-14. https://doi.org/10.3389/fmars.2018.00474.

Koch, E.W. 2001. Beyond light: physical, geological, and geochemical parameters as possible submersed aquatic vegetation habitat requirements. Estuaries 24 (1): 1-17.

Krishnaswami, S., D. Lal, J.M. Martin, and M. Meybeck. 1971. Geochronology of lake sediments. Earth and Planetary Science Letters 11 (1-5): 407-414.

Lavery, P.S., M.-Á. Mateo, O. Serrano, and M. Rozaimi. 2013. Variability in the carbon storage of seagrass habitats and its implications for global estimates of blue carbon ecosystem service. PLoS One 8 (9): e73748.

Lee, K.-S., F.T. Short, and D.M. Burdick. 2004. Development of a nutrient pollutant indicator using the eelgrass Zostera marina along nutrient gradients in three New England estuaries. Aquatic Botany 78 (3): 197-216.

Lovelock, C.E., T. Atwood, J. Baldock, C.M. Duarte, S.S. Hickey, P.S.P. Masque Lavery, P.I. Macreadie, A.M. Ricart, O. Serrano, and A. Steven. 2017. Assessing the risk of carbon dioxide emissions from blue carbon ecosystems. Frontiers in Ecology and the Environment 15 (5): 257-265.

Macreadie, P.I., P.M. York, C.D.H. Sherman, M.J. Keough, D.J. Ross, A.M. Ricart, and T.M. Smith. 2014. No detectable impact of smallscale disturbances in 'blue carbon' within seagrass beds. Marine Biology 161 (12): 2939-2944.

Macreadie, P.I., S.M. Trevathan-Tackett, C.G. Skilbeck, J. Sanderman, N. Curlevski, G. Jacobsen, and J.R. Seymour. 2015. Loss and recovery of organic carbon from a seagrass ecosystem following disturbance. Proceedings of the Royal Society B 282 (1817): 20151537.

Macreadie, P.I., D.A. Nielsen, J.J. Kelleway, T. Atwood, J. Seymour, K. Petrou, R.M. Connolly, A.C.G. Thomson, S. Trevathan-Tackett, and P. Ralph. 2017. Can we manage coastal ecosystems to sequester more blue carbon? Frontiers in Ecology and the Environment 15 (4): 206-213.

Macreadie, P.I., C.J. Ewers-Lewis, A.A. Whitt, Q. Ollivier, S.M. Trevathan-Tackett, P. Carnell, and O. Serrano. 2018. Comment on 'Geoengineering with seagrasses: is credit due where credit is given? Environmental Research Letters 13: 028002.

Marba, N., A. Arias-Ortiz, P. Masque, G.A. Kendrick, I. Mazarassa, G.R. Bastyan, J. Garcia-Orellana, and C.M. Duarte. 2015. Impact of seagrass loss and subsequent revegetation on carbon sequestration and stocks. Journal of Ecology 103 (2): 296-302.

Masqué, P., E. Isla, J.A. Sanchez-Cabeza, A. Alanques, J.M. Bruach, P. Puig, and J. Guillén. 2002. Sediment accumulation rates and carbon fluxes to bottom sediments at the Western Bransfield Strait (Antarctica). Deep Sea Research Part II: Topical Studies in Oceanography 49 (4-5): 921-933.

Mateo, M., J. Cebrián, K. Dunton, and T. Mutchler. 2006. Carbon flux in seagrass ecosystems. In Seagrasses: Biology, ecology, and conservation, ed. A.W.D. Larkum, R.J. Orth, and C.M. Duarte, 159-192. Dordrecht: Springer.

Mazarrasa, I., N. Marbà, J. Garcia-Orellana, P. Masqué, A. Arias-Ortiz, and C.M. Duarte. 2017. Effect of environmental factors (wave exposure and depth) and anthropogenic pressure in the $\mathrm{C}$ sink capacity of Posidonia oceanica meadows: effect of environmental factors and anthropogenic pressure. Limnology and Oceanography 62 (4): $1436-1450$.

Mazarrasa, I., N. Marbà, C.E. Lovelock, O. Serrano, P.S. Lavery, J.W. Fourqurean, H. Kennedy, M.A. Mateo, D. Krause-Jensen, A.D.L. Steven, and C.M. Duarte. 2018. Habitat characteristics provide insights of carbon storage in seagrass meadows. Marine Pollution Bulletin 134: 106-117.

Mcleod, E., G.L. Chmura, S. Bouillon, R. Salm, M. Björk, C. Duarte, C.E. Lovelock, W. Schlesinger, and B.R. Silliman. 2011. A blueprint for blue carbon: toward an improved understanding of the role 
of vegetated coastal habitats in sequestering $\mathrm{CO}_{2}$. Frontiers in Ecology and the Environment 9 (10): 552-560.

Miyajima, T., M. Hori, M. Hamaguchi, H. Shimabukuro, and G. Yoshida. 2017. Geophysical constraints for organic carbon sequestration capacity of Zostera marina seagrass meadows and surrounding habitats. Limnology and Oceanography 62 (3): 954-972.

Neckles, H. A., A. R. Hanson, P. Colarusso, R. N. Buchsbaum, and F. T. Short. 2009. Status, trends, and conservation of eelgrass in Atlantic Canada and the Northeastern United States. https://www. cascobayestuary.org/wp-content/uploads/2014/08/2009_eelgrass_ workshop report.pdf. Accessed 27 March 2019.

Nellemann, C., E. Corcoran, C.M. Duarte, and L. Valdes. 2009. Blue carbon - the role of healthy oceans in binding carbon. Norway: United Nations Environment Programme, GRID-Arendal.

Oreska, M.P.J., K.J. McGlathery, and J.H. Porter. 2017. Seagrass blue carbon spatial patterns at the meadow-scale. PLoS One 12 (4): e0176630. https://doi.org/10.1371/journal.pone.0176630.

Orth, R.J., M.C. Harwell, E.M. Baily, A. Bartholomew, J.T. Jawad, A.V. Lombana, K.A. Moore, J.M. Rhode, and H.E. Woods. 2000. A review of issues in seagrass seed dormancy and germination: implications for conservation and restoration. Marine Ecology Progress Series 200: 277-288.

Orth, R.J., T.J.B. Carruthers, W.C. Dennison, C.M. Duarte, J.W. Fourqurean, K.L. Heck, A.R. Hughes, G.A. Kendrick, W.J. Kenworthy, S. Olyarnik, F.T. Short, M. Waycott, and S.L. Williams. 2006. A global crisis for seagrass ecosystems. BioScience 56 (12): 987-996.

Röhr, M.E., C. Boström, P. Canal-Vergés, and M. Holmer. 2016. Blue carbon stocks in Baltic Sea eelgrass (Zostera marina) meadows. Biogeosciences 13 (22): 6139-6153.

Röhr, M.E., M. Holmer, J.K. Baum, M. Björk, K. Boyer, D. Chin, L. Chalifour, S. Cimon, M. Cusson, M. Dahl, D. Deyanova, J.E. Duffy, J.S. Eklöf, J.K. Geyer, J.N. Griffin, M. Gullström, C.M. Hereu, M. Hori, K.A. Hovel, A.R. Hughes, P. Jorgensen, S. Kiriakopolos, P.O. Moksnes, M. Nakaoka, M.I. O'Connor, B. Peterson, K. Reiss, P. Reynolds, F. Rossi, J. Ruesink, R. Santos, J.J. Stachowicz, F. Tomas, K.-S. Lee, R.K.F. Unsworth, and C. Boström. 2018. Blue carbon storage capacity of temperate eelgrass (Zostera marina) meadows. Global Biogeochemical Cycles 32: 1457-1475.

Samper-Villarreal, J., C.E. Lovelock, M.I. Saunders, C. Roelfsema, and P.J. Mumby. 2016. Organic carbon in seagrass sediments is influenced by seagrass canopy complexity, turbidity, wave height, and water depth. Limnography and Oceanography 61 (3): 938-952.

Samper-Villarreal, J., P. Mumby, M.I. Saunders, L. Barry, A. Zawadzki, H. Heijnis, G. Morelli, and C.E. Lovelock. 2017. Vertical accretion and carbon burial rates in subtropical seagrass meadows increased following anthropogenic pressure from European colonization. Estuarine, Coastal and Shelf Science 202: 40-53. https://doi.org/ 10.1016/j.ecss.2017.12.006.

Sanchez-Cabeza, J.A., P. Masqué, and I. Ani-Ragolta. $1998 .{ }^{210} \mathrm{~Pb}$ and

${ }^{210} \mathrm{Po}$ analysis in sediments and soils by microwave acid digestion. Journal of Radioanalytical and Nuclear Chemistry 227 (1-2): 1922.

Schmidt, A.L., J.K.C. Wysmyk, S.E. Craig, and H.K. Lotze. 2012. Regional-scale effects of eutrophication on ecosystem structure and services of seagrass beds. Limnology and Oceanography 57 (5): 1389-1402. https://doi.org/10.4319/lo.2012.57.5.1389.
Serrano, O., P.S. Lavery, M. Rozaimi, and M.-Á. Mateo. 2014. Influence of water depth on the carbon sequestration capacity of seagrasses. Global Biogeochemical Cycles 28 (9): 950-961.

Serrano, O., R. Ruhon, P.S. Lavery, G.A. Kendrick, S. Hickey, P. Masqué, A. Arias-Ortiz, A. Steven, and C.M. Duarte. 2016a. Impact of mooring activities on carbon stocks in seagrass meadows. Scientific Reports 6 (1): 23193.

Serrano, O., P.S. Laverly, C.M. Duarte, G.A. Kendrick, A. Calafat, P.H York, A. Steven, and P.I. Macreadie. 2016b. Can mud (silt and clay) concentration be used to predict soil organic carbon content within seagrass ecosystems? Biogeosciences 13: 4415-4926.

Short, F.T. 1987. Effects of sediment nutrients on seagrasses: literature review and mesocosm experiment. Aquatic Botany 21: 41-57.

Short, F.T., and C.M. Duarte. 2001. Methods for the measurement of seagrass growth and production. In Global Seagrass research methods, ed. F.T. Short and R.G. Coles, 155-182. Amsterdam: Elsevier Science B.V.

Short, F.T., and J.E. Kaldy. 1995. Mesocosm experiments quantify the effects of eutrophication on eelgrass, Zostera marina. Limnology and Oceangraphy 40 (4): 740-749.

Short, F.T., and S. Wyllie-Echeverria. 1996. Natural and human-induced disturbances of seagrasses. Environmental Conservation 23: 12-27.

Short, F.T., E.W. Koch, J.C. Creed, E.F. Magalhäes, and J.L. Gaekle. 2006. SeagrassNet monitoring across the Americas: case studies of seagrass decline. Marine Ecology 2: 277-289.

Short, F.T., T. Carruthers, W. Dennison, and M. Waycott. 2007. Global seagrass distribution and diversity: a bioregional model. Journal of Experimental Marine Biology and Ecology 350 (1-2): 3-20.

Smith, N.P. 1981. Energy balance in a shallow seagrass flat for winter conditions. Limnology and Oceanography 26 (3): 482-491.

Trevathan-Tackett, S.M., J. Seymour, D. Neilsen, P.I. Macreadie, J. Thomas, J. Sanderman, J. Baldock, J. Howes, A. Steven, and P. Ralph. 2017a. Sediment anoxia limits microbial-driven seagrass carbon remineralization under warming conditions. FEMS Microbiology Ecology 93: fix033. https://doi.org/10.1093/femsec/ fix033.

Trevathan-Tackett, S.M., C. Wessel, J. Cebrian, P.J. Ralph, P. Masque, and P.I. Macreadie. 2017b. Effects of small-scale, shading induced seagrass loss on blue carbon storage: implications for management of degraded seagrass ecosystems. Journal of Applied Ecology 55: $1351-1359$.

Twilley, R.R., W.M. Kemp, K.W. Staver, J.C. Stevenson, and W.R. Boynton. 1985. Nutrient enrichment of estuarine submersed vascular plant communities. 1. Algal growth and effects on production of plants and associated communities. Marine Ecology Progress Series 23: 179-191.

Unsworth, R.K.F., C.J. Collier, M. Waycott, L.J. Mckenzie, and L.C. Cullen-Unsworth. 2015. A framework for the resilience of seagrass ecosystems. Marine Pollution Bulletin 100 (1): 34-46.

Vichkovitten, T., and M. Holmer. 2004. Contribution of plant carbohydrates to sedimentary carbon mineralization. Organic Geochemistry 35 (9): 1053-1066. https://doi.org/10.1016/j.orggeochem.2004.04. 007.

Waycott, M., C.M. Duarte, T.J.B. Carruthers, R.J. Orth, W.C. Dennison, S. Olyarnik, A. Calladine, J.W. Fourqurean, K.L. Heck Jr., A.R. Hughes, G.A. Kendrick, W.J. Kenworthy, F.T. Short, and S.L. Williams. 2009. Accelerating loss of seagrasses across the glove threatens coastal ecosystems. PNAS 106 (30): 12377-12381. 